\title{
Response of water temperatures and stratification to changing climate in three lakes with different morphometry
}

\author{
Madeline R. Magee ${ }^{1,2}$ and Chin H. Wu ${ }^{1}$ \\ ${ }^{1}$ Department of Civil and Environmental Engineering, University of Wisconsin-Madison, \\ Madison, WI 53706, USA \\ ${ }^{2}$ Center of Limnology, University of Wisconsin-Madison, Madison, WI 53706, USA \\ Correspondence: Chin H. Wu (chinwu@engr.wisc.edu)
}

Received: 27 May 2016 - Discussion started: 26 July 2016

Revised: 13 October 2017 - Accepted: 2 November 2017 - Published: 11 December 2017

\begin{abstract}
Water temperatures and stratification are important drivers for ecological and water quality processes within lake systems, and changes in these with increases in air temperature and changes to wind speeds may have significant ecological consequences. To properly manage these systems under changing climate, it is important to understand the effects of increasing air temperatures and wind speed changes in lakes of different depths and surface areas. In this study, we simulate three lakes that vary in depth and surface area to elucidate the effects of the observed increasing air temperatures and decreasing wind speeds on lake thermal variables (water temperature, stratification dates, strength of stratification, and surface heat fluxes) over a century (19112014). For all three lakes, simulations showed that epilimnetic temperatures increased, hypolimnetic temperatures decreased, the length of the stratified season increased due to earlier stratification onset and later fall overturn, stability increased, and longwave and sensible heat fluxes at the surface increased. Overall, lake depth influences the presence of stratification, Schmidt stability, and differences in surface heat flux, while lake surface area influences differences in hypolimnion temperature, hypolimnetic heating, variability of Schmidt stability, and stratification onset and fall overturn dates. Larger surface area lakes have greater wind mixing due to increased surface momentum. Climate perturbations indicate that our larger study lakes have more variability in temperature and stratification variables than the smaller lakes, and this variability increases with larger wind speeds. For all study lakes, Pearson correlations and climate perturbation scenarios indicate that wind speed has a large effect on temperature and stratification variables, sometimes greater than
\end{abstract}

changes in air temperature, and wind can act to either amplify or mitigate the effect of warmer air temperatures on lake thermal structure depending on the direction of local wind speed changes.

\section{Introduction}

The past century has experienced global changes in air temperature and wind speed. Land and ocean surface temperature anomalies relative to 1961-1990 increased from 1850 to 2012 (IPCC, 2013). Mean temperature anomaly across the continental United States has increased (Hansen et al., 2010), and studies suggest that more intense and longer lasting heat waves will continue in the future (Meehl and Tebaldi, 2004). Additionally, global change in wind speed has been heterogenous. For example, wintertime wind energy increased in northern Europe (Pryor et al., 2005), but other parts of Europe have experienced decreases in wind speed in part due to increased surface roughness (Vautard et al., 2010), while modest declines in mean wind speeds were observed in the United States (Breslow and Sailor, 2002). Similarly, on regional scales, Magee et al. (2016) showed a decrease in Madison, Wisconsin, wind speeds after 1994, but Austin and Colman (2007) found increased wind speeds in Lake Superior, North America. Significant changes to air temperature and wind speed observed in the contemporary and historical periods are likely to continue to change in the future.

Lake water temperature is closely related to air temperature and wind speed. Previous studies have mainly focused on warming air temperatures, showing increased epilimnetic 
water temperatures (Dobiesz and Lester, 2009; Ficker et al., 2017; O'Reilly et al., 2015; Shimoda et al., 2011), increased strength of stratification (Hadley et al., 2014; Rempfer et al., 2010), prolonged stratified period (Ficker et al., 2017; Livingstone, 2003; Woolway et al., 2017a), and altered thermocline depth (Schindler et al., 1990). However, hypolimnetic temperatures have undergone warming, cooling, and no temperature increase (Butcher et al., 2015; Ficker et al., 2017; Magee et al., 2016; Shimoda et al., 2011). Wind speed also strongly affects lake mixing (Boehrer and Schultze, 2008), lake heat transfer (Boehrer and Schultze, 2008; Read et al., 2012), and temperature structure (Desai et al., 2009; Schindler et al., 1990). Stefan et al. (1996) found that decreasing wind speeds resulted in increased stratification and increased epilimnetic temperatures in inland lakes. Similarly, Woolway et al. (2017a) found that decreasing wind speeds increased days of stratification for a polymictic lake in Europe. In Lake Superior, observations show that the complex non-linear interactions among air temperature, ice cover, and water temperature result in water temperature increases (Austin and Allen, 2011), contrary to the expected decreases in water temperature from increased wind speeds (Desai et al., 2009). In recent years, our understanding of the effects of air temperature and wind speed on changes in water temperature and stratification has improved (Kerimoglu and Rinke, 2013; Magee et al., 2016; Woolway et al., 2017a), but research on the response of lakes to isolated and combined changes in air temperature and wind speed has been limited.

Changes in lake water temperature influence lake ecosystem dynamics (MacKay et al., 2009). For example, increasing water temperatures may change plankton community composition and abundance (Rice et al., 2015), alter fish populations (Lynch et al., 2015), and enhance the dominance of cyanobacteria (Jöhnk et al., 2008). Such changes affect the biodiversity of freshwater ecosystems (Mantyka-Pringle et al., 2014). Furthermore, increased thermal stratification of lakes can intensify lake anoxia (Ficker et al., 2017; Palmer et al., 2014), increase bloom-forming cyanobacteria (Paerl and Paul, 2012), and change internal nutrient loading and lake productivity (Ficker et al., 2017; Verburg and Hecky, 2009). Variations in water temperature impact the distribution, behavior, community composition, reproduction, and evolutionary adaptations of organisms (Thomas et al., 2004). Improved understanding of the response of lake water temperatures and ecosystem response to air temperature and wind speed can better prepare management, adaptation, and mitigation efforts for a range of lakes.

Lake morphometry complicates the response of lake water temperatures to air temperature and wind speed changes because it alters physical processes of wind mixing, water circulation, and heat storage (Adrian et al., 2009). Mean depth, surface area, and volume strongly affect lake stratification (Butcher et al., 2015; Kraemer et al., 2015). Large surface areas increase the effects of vertical wind mixing, an important mechanism for transferring heat to the lake bot- tom (Rueda and Schladow, 2009), and changes in thermocline depth from warming air temperatures may be dampened in large lakes where thermocline depth is constrained by lake fetch (Boehrer and Schultze, 2008; MacIntyre and Melack, 2010). Lake size has been demonstrated to influence the relative contribution of wind and convective mixing to gas transfer (Read et al., 2012), and lake size can influence the magnitude of diurnal heating and cooling in lakes (Woolway et al., 2016), which both have implications for calculating metabolism and carbon emissions in inland waters (Holgerson et al., 2017). Winslow et al. (2015) showed that differences in wind-driven mixing may explain the inconsistent response of hypolimnetic temperatures between small and large lakes. Previous research efforts have investigated the response of individual lakes (Voutilainen et al., 2014) and the bulk response of lakes in a geographic region to changing climate (Kirillin, 2010; Magnuson et al., 1990), but few studies have focused on elucidating the effects of morphometry, specifically lake depth and surface area, on changes in lake water temperature in response to long-term changes in air temperature and wind speed.

The purpose of this paper is to investigate the response of water temperatures and stratification in lakes with different morphometry (water depth and surface area) to changing air temperature and wind speed. To do this, we employ an existing one-dimensional hydrodynamic lake-ice model to hindcast water temperatures for three lakes with different morphometry. These lakes vary in surface area and depth and are near one another $(<30 \mathrm{~km}$ distance $)$ to experience similar daily climate conditions (air temperature, wind speed, solar radiation, cloud cover, precipitation) over the century period (1911-2014). By examining three lakes in the same ecoregion with similar climate forcing, we aim to elucidate differences in responses that relate to morphometry rather than climatic variables. Long-term changes in water temperature, stratification, heat fluxes, and stability are used to investigate how lake depth and surface area alter the response of thermal structure to air temperature and wind speed changes for the three study lakes.

\section{Methods}

\subsection{Study sites}

Three morphometrically different lakes, Lake Mendota, Fish Lake, and Lake Wingra, located near Madison, Wisconsin, United States of America (USA), were selected for this study. These lakes are chosen for (i) their morphometry differences, (ii) their proximity to one another, and (iii) the availability of long-term data for model input and calibration.

Lake Mendota $\left(43^{\circ} 6^{\prime} \mathrm{N}\right.$; $89^{\circ} 24^{\prime} \mathrm{W}$; Fig. 1a; Table 1), is a dimictic, eutrophic drainage lake in an urbanizing agricultural watershed (Carpenter and Lathrop, 2008). The lake stratifies during the summer, and typical stratification peri- 

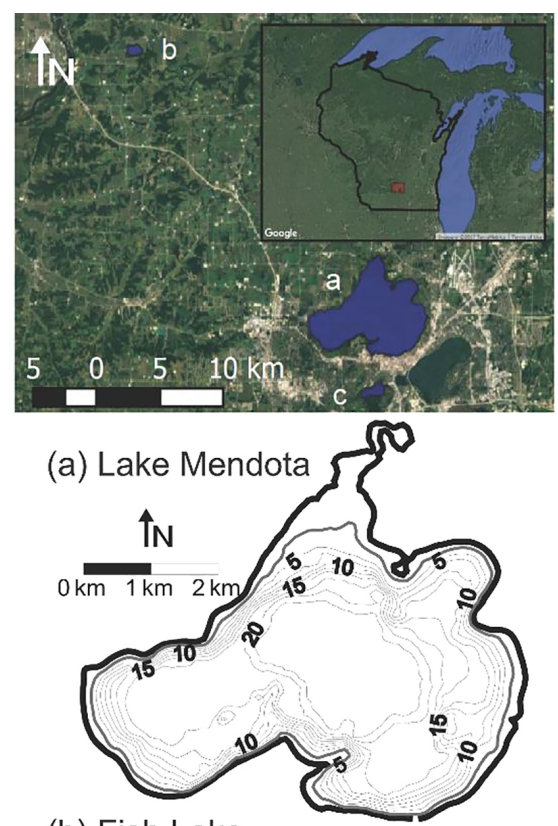

(b) Fish Lake
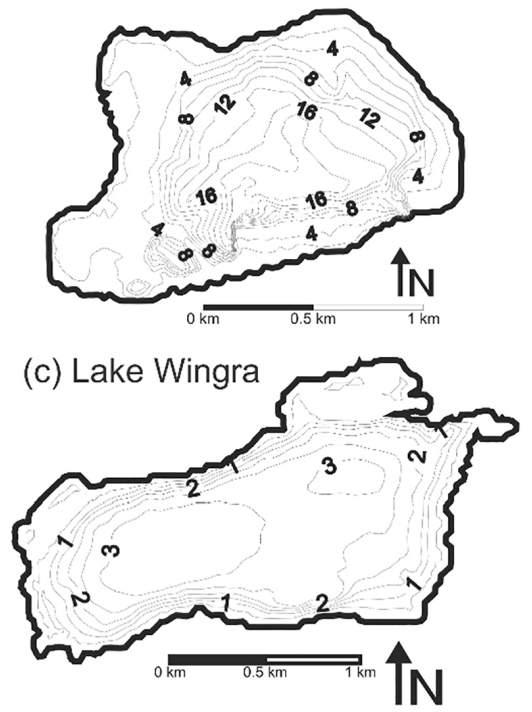

Figure 1. (Top) map of study lakes in Wisconsin, USA and bathymetric maps of each lake: (a) Lake Mendota, (b) Fish Lake, and (c) Lake Wingra.

ods last from May to September. Summer (1 June-31 August) mean surface water temperature is $22.4^{\circ} \mathrm{C}$, and hypolimnetic temperatures vary between 11 and $15^{\circ} \mathrm{C}$. Normal Secchi depth during the summer is $3.0 \mathrm{~m}$ (Lathrop et al., 1996). Fish Lake $\left(43^{\circ} 17^{\prime} \mathrm{N}\right.$; $89^{\circ} 39^{\prime} \mathrm{W}$; Fig. 1b; Table 1$)$ is a dimictic, eutrophic, shallow seepage lake located in northwestern Dane County. From 1966 to 2001, the lake level rose by $2.75 \mathrm{~m}$ due to increased groundwater flow from higherthan-normal regional groundwater recharge (Krohelski et al., 2002). Krohelski et al. (2002) hypothesized that the increase in recharge may be the result of increased infiltration from snowmelt after increased snowfall and less frost-covered soil.
Summer stratification lasts from the beginning of May to mid-September. Mean surface water temperature is $23.9^{\circ} \mathrm{C}$, and hypolimnetic temperatures are normally near $8^{\circ} \mathrm{C}$ during the summer months; however, some years reach temperatures of only $5-6^{\circ} \mathrm{C}$ in the hypolimnion due to shortened spring mixing durations. Average Secchi depth during the summer months is $2.4 \mathrm{~m}$. Lake Wingra $\left(43^{\circ} 3^{\prime} \mathrm{N} ; 8^{\circ} 26^{\prime} \mathrm{W}\right.$; Fig. 1c; Table 1) is a shallow eutrophic drainage lake. It stratifies on short timescales of hours to weeks (Kimura et al., 2016) but does not experience sustained thermal stratification. Summer mean water temperature is $23.9^{\circ} \mathrm{C}$, and mean Secchi depth is $0.7 \mathrm{~m}$. All three lakes have ice cover during the winter months, and a description of ice on the lakes can be found in Magee and Wu (2017).

\subsection{Model description}

To hindcast water temperature and stratification in the three study lakes, we use the vertical heat transfer model, DYRESM-WQ (DYnamic REservoir Simulation Model for Water Quality) by Hamilton and Schladow (1997), which employs discrete horizontal Lagrangian layers to simulate vertical water temperature, salinity, and density with input including inflows, outflows, and mixing (Imberger et al., 1978). The model has been previously used on a variety of lake types and is accepted as a standard for hydrodynamic lake modeling (Gal et al., 2003; Hetherington et al., 2015; Imberger and Patterson, 1981; Kara et al., 2012; Tanentzap et al., 2007). DYRESM-WQ adopts a one-dimensional layer structure based on the importance of vertical density stratification over horizontal density variations. A one-dimensional assumption is based on observations that the density stratification found in lakes inhibits vertical motions, while horizontal variations in density relax due to horizontal advection and convection (Antenucci and Imerito, 2003; Imerito, 2010). Surface exchanges include heating due to shortwave radiation penetration into the lake and surface fluxes of evaporation, sensible heat, longwave radiation, and wind stress (Imerito, 2010). Surface layer mixing is based on potential energy required for mixing, and introduction of turbulent kinetic energy through convective mixing, wind stirring, and shear mixing (Imerito, 2010; Yeates and Imberger, 2003). Layer mixing occurs when the turbulent kinetic energy (TKE), stored in the topmost layers, exceeds a potential energy threshold (Yeates and Imberger, 2003). To represent convective overturn, layers are checked for instabilities resulting from surface cooling, and if they exist, layers are merged and a fraction of the potential energy released becomes available as TKE. To represent wind stirring, wind stress is calculated from the wind speed and TKE is produced in the uppermost layer. Upper layers will mix with lower layers if TKE is greater than the energy required for mixing. Mixing by shear flow is determined by calculating the mean horizontal velocity of the uppermost layer, which is dependent on the critical wind speed and the shear pe- 
Table 1. Lake characteristics for the three study lakes.

\begin{tabular}{llll}
\hline & Lake Mendota & Fish Lake & Lake Wingra \\
\hline Mean depth $(\mathrm{m})$ & 12.8 & 6.6 & 2.7 \\
Maximum depth $(\mathrm{m})$ & 25.3 & 18.9 & 4.7 \\
Surface area $(\mathrm{ha})$ & 3937.7 & 87.4 & 139.6 \\
Shoreline length $(\mathrm{km})$ & 33.8 & 4.3 & 5.9 \\
Lake fetch $(\mathrm{km})$ & 9.2 & 1.2 & 2.0 \\
Shoreline development & High & High & High \\
Landscape position & Low & High & High \\
Secchi depth $(\mathrm{m})^{\mathrm{a}}$ & 3.0 & 2.4 & 0.7 \\
Chlorophyll $\left(\mu \mathrm{g} \mathrm{L} \mathrm{L}^{-1}\right)^{\mathrm{b}}$ & 4.8 & 5.1 & 10.5 \\
Dissolved organic carbon $\left(\mu \mathrm{g} \mathrm{L}^{-1}\right)^{\mathrm{c}}$ & 5.71 & 6.95 & 7.01 \\
Lake type & Drainage & Seepage & Drainage \\
Groundwater inflow type & Discharge & Flowthrough & Flowthrough \\
Groundwater input $(\%)$ & 30 & 6 & 35 \\
\hline
\end{tabular}

${ }^{a}$ Secchi depth measured from 1 June to 31 August. ${ }^{b}$ Surface chlorophyll from the open-water season. ${ }^{c}$ Dissolved organic carbon is the average of all measurements for each lake.

riod. Yeates and Imberger (2003) improved performance of the surface mixed layer routine within the model by including an effective surface area algorithm based on observations in five lakes of different size, shape, and wind forcing characteristics (see Eq. 32 in Yeates and Imberger, 2003) that reduced surface mixing in smaller, more sheltered lakes. The effective area is used to modify the transfer of momentum from surface stress, as described in detail in Yeates and Imberger (2003) and not reproduced here. Their analysis developed a strong inverse relationship between the lake number and lake-wide average vertical eddy diffusion coefficient, which configures a pseudo two-dimensional deep mixing within the code, found to significantly improve the simulation of thermal structures observed in lakes that experienced strong wind forcing (Yeates and Imberger, 2003). Details of the surface mixed layer algorithm are not reproduced here but can be found in Eqs. (27)-(34) of Yeates and Imberger (2003). Hypolimnetic mixing is parameterized through a vertical eddy diffusion coefficient, which accounts for turbulence created by the damping of basin-scale internal waves on the bottom boundary and lake interior (Yeates and Imberger, 2003). Detailed equations on the simulation of water temperature and mixing can be found in Imberger and Patterson (1981), Imerito (2010), and Yeates and Imberger (2003).

Sediment heat flux is included as a source/sink term for each model layer. A diffusion relation from Rogers et al. (1995) is used to estimate $q_{\text {sed }}$, heat transfer from the sediments to the water column.

$q_{\mathrm{sed}}=K_{\mathrm{sed}} \frac{\mathrm{d} T}{\mathrm{~d} z}$,

where $K_{\text {sed }}$ represents the sediment conductivity with a value of $1.2 \mathrm{Wm}^{-1}{ }^{\circ} \mathrm{C}^{-1}$ (Rogers et al., 1995), and $\mathrm{d} T / \mathrm{d} z$ is estimated as $\frac{\mathrm{d} T}{\mathrm{~d} z}=\frac{T_{\mathrm{s}}-T_{\mathrm{w}}}{z_{\mathrm{sed}}}$,

where $\mathrm{d} T / \mathrm{d} z$ is the temperature gradient across the sediment-water interface, $T_{\mathrm{w}}$ is the water temperature adjacent to the sediment boundary, and $z_{\text {sed }}$ is the distance beneath the water-sediment interface at which the sediment temperature becomes relatively invariant and is taken to be $5 \mathrm{~m}$ (Birge et al., 1927). $T_{\mathrm{s}}$ is derived from Birge et al. (1927) and seasonally variant as follows:

$T_{\mathrm{s}}=9.7+2.7 \sin \left[\frac{2 \pi(D-151)}{\mathrm{TD}}\right]$,

where $D$ is the number of days from the start of the year and TD is the total number of days within a year.

The ice component of the model, DYRESM-WQ-I, is based on the three-component MLI model of Rogers et al. (1995), with the additions of two-way coupling of the hydrodynamic and ice models and time-dependent sediment heat flux for all horizontal layers. The model assumes that the timescale for heat conduction through the ice is short relative to the timescale of meteorological forcing (Patterson and Hamblin, 1988; Rogers et al., 1995), an assumption which is valid with a Stefan number less than 0.1 (Hill and Kucera, 1983). The three-component ice model simulates blue ice, white ice, and snow thickness (see Eq. 1 and Fig. 5 of Rogers et al., 1995). Further description of the ice model can be found in Magee et al. (2016) and Hamilton et al. (2017). Details on ice cover simulations in response to changing climate for the three lakes can be found in Magee and Wu (2017).

Model inputs include lake hypsography, initial vertical profiles for water temperature and salinity, Secchi depth, meteorological variables, and inflows/outflows. The model calculates the surface heat fluxes using meteorological variables: total daily shortwave radiation, daily cloud cover, air 
vapor pressure, daily average wind speed, air temperature, and precipitation. Water temperature, water budget, and ice thickness are calculated at $1 \mathrm{~h}$ time steps. Snow ice compaction, snowfall, and rainfall components are updated at a daily time step, corresponding to the frequency of meteorological data input. Cloud cover, air pressure, wind speed, and temperature are assumed constant throughout the day, and precipitation is assumed uniformly distributed. Shortwave radiation distribution throughout the day is computed based on lake latitude and the Julian day (Antenucci and Imerito, 2003). Parameters relevant to the open-water period are provided in Table 2. Ice cover model parameters can be found in Hamilton et al. (2017), Magee and Wu (2017), and Magee et al. (2016). During the entire simulation period, all model parameters and coefficients are kept constant. Simulations were run for all three lakes starting on 7 April 1911 and ending on 31 October 2014 without termination.

\subsection{Data}

\subsubsection{Lake morphometry}

Height $(\mathrm{m})$, area $\left(\mathrm{m}^{2}\right)$, and volume $\left(\mathrm{m}^{3}\right)$ which describe the hypsographic curves for each lake were calculated using bathymetric maps of each lake from the Wisconsin Department of Natural Resources.

\subsubsection{Initial conditions}

Initial conditions for each lake include temperature and salinity profiles for the first days of the simulations. For Lake Mendota, initial conditions were obtained from the North Temperate Lakes Long-Term Ecological Research (NTLLTER) program database on the first day of simulation. For Fish Lake and Lake Wingra, initial conditions after ice-off were unavailable for 1911 and were assumed to be the average of all available initial conditions for the lake from \pm 7 days of the Julian start date for all years with available data.

\subsubsection{Light extinction coefficient}

Seasonal Secchi depths within each year were used to determine the light extinction coefficients. Lathrop et al. (1996) compiled Secchi depth data for Lake Mendota between 1900 and 1993 (1701 daily Secchi depth readings from 70 calendar years), and summarized the data for six seasonal periods: winter (ice-on to ice-out), spring turnover (ice-out to 10 May), early stratification (11 May to 29 June), summer (30 June to 2 September), destratification (3 September to 12 October), and fall turnover (13 October to ice-on). After 1993, Secchi depths are obtained from the NTL-LTER program (https://portal.Iternet.edu/nis/home.jsp\#). Open-water and under-ice Secchi depths were collected for various longterm ecological research studies, including the NTL-LTER study, and used here to better characterize temperature pro-
Table 2. DYRESM-WQ-I model parameters. Ice cover parameter can reference Magee et al. (2016) and Magee and Wu (2016).

\begin{tabular}{|c|c|}
\hline Parameter & Value \\
\hline Albedo & $0.08^{\mathrm{a}, \mathrm{b}}$ \\
\hline Bulk aerodynamic momentum transport coefficient & $0.00139^{\mathrm{b}}$ \\
\hline Critical wind speed $\left(\mathrm{m} \mathrm{s}^{-1}\right)$ & $4.3^{\mathrm{b}}$ \\
\hline Effective surface area coefficient $\left(\mathrm{m}^{2}\right)$ & $1 \times 10^{7 \mathrm{c}}$ \\
\hline Emissivity of water surface & $0.96^{\mathrm{d}}$ \\
\hline Potential energy mixing efficiency & $0.2^{\mathrm{a}, \mathrm{b}}$ \\
\hline Shear production efficiency & $0.06^{\mathrm{a}, \mathrm{b}, \mathrm{c}}$ \\
\hline Vertical mixing coefficient & $200^{\mathrm{c}}$ \\
\hline Wind stirring efficiency & $0.8^{\mathrm{b}}$ \\
\hline Minimum layer thickness & $0.125^{*}$ \\
\hline Maximum layer thickness & $0.6^{\mathrm{b}}$ \\
\hline Vertical light attenuation coefficient & variable $\mathrm{e}^{\mathrm{e}}$ \\
\hline
\end{tabular}

files throughout the year including under ice cover. Secchi depth data for Fish Lake and Lake Wingra were available only from 1995 to the present and collected from the NTLLTER program. For years with no Secchi data, the long-term mean seasonal Secchi depths were used. There is no significant long-term trend in yearly averaged open-water Secchi depth values for any of the three lakes. Light extinction coefficients were estimated from Secchi depth using the equation from Williams et al. (1980):

$k_{d}=1.1 / z_{\mathrm{s}}^{0.73}$,

where $k_{d}$ is the light extinction coefficient and $z_{\mathrm{s}}$ is the Secchi depth (m).

\subsubsection{Meteorological data}

Meteorological data used to hindcast the historical period consisted of daily solar radiation, air temperature, vapor pressure, wind speed, cloud cover, rainfall, and snowfall over a period of 104 years from 1911 to 2014. Air temperature, wind speed, vapor pressure, and cloud cover were computed as an average of the whole day, while solar radiation, rainfall, and snowfall were the daily totals. Meteorological data were gathered from Robertson (1989), who compiled a continuous daily meteorological dataset for Madison, Wisconsin, from 1884 to 1988 by adjusting for changes in site location. Appended to this dataset are data from the National Climate Data Center weather station at the Dane County Regional Airport. All data other than solar radiation can be obtained from http://www.ncdc.noaa.gov/ for Madison (MSN), and solar radiation can be obtained from http://www.sws. uiuc.edu/warm/weather/. Adjustments to wind speed were made based on changes in observational techniques occurring in 1996 (McKee et al., 2000) by comparing data from Dane County Regional Airport with those collected from 
the Atmospheric and Oceanic Space Sciences Building instrumentation tower at the University of Wisconsin-Madison (http://metobs.ssec.wisc.edu/pub/cache/aoss/tower/). Details of this adjustment can be found in Magee et al. (2016) and Hsieh (2012).

\subsubsection{Inflow and outflow data}

Daily inflow and outflow data for Lake Mendota were obtained and described in detail by Magee et al. (2016). Details of data collection and gap-filling can be found there and are not reproduced for brevity. Inflow and outflow data for Fish Lake and Lake Wingra follow a similar process. Inflow and outflow were estimated as the residual unknown terms of the water budget balancing precipitation, evaporation, and lake level. USGS water level data from 1966 to 2003 (http://waterdata.usgs.gov/wi/nwis/dv/?site_no= 05406050\&agency_cd=USGS\&amp;referred_module=sw) were used to estimate inflow and outflow from surface runoff and groundwater inflow. For early years of simulation, where lake level information was not available, the long-term mean lake level was assumed for calculations. Krohelski et al. (2002) determined that surface runoff accounted for two-thirds of inflowing water while groundwater inflow accounted for one-third of total inflow over the period 1990-1991. Using these values, we attributed two-thirds of the inflowing water as surface runoff using air temperatures to estimate the runoff temperature similar to the method for Lake Mendota in Magee et al. (2016) and one-third of inflowing water as groundwater inflow using an average of groundwater temperature measurements (Hennings and Connelly, 2008). For Lake Wingra, water level was recorded sporadically during the period of interest, and was assumed to be the long-term mean lake level for water budget calculations. As in Fish Lake, Lake Wingra has no surface inflow streams, with inflow values attributed equally to direct precipitation, surface runoff, and groundwater inflow (Kniffin, 2011). Groundwater inflow temperatures were estimated using an average of measurements (Hennings and Connelly, 2008), and surface and direct precipitation were estimated as air temperature.

\subsubsection{Observation data}

Observation data used for model calibration came from a variety of sources. For Lake Mendota, long-term water temperature records were collected from Robertson (1989) and the NTL-LTER (2012b). Ice thickness data were gathered from E. Birge, University of Wisconsin (unpublished); D. Lathrop, Wisconsin Department of Natural Resources (unpublished); Stewart (1965); and the NTL-LTER program (2012a). Frequency of temperature data varied from one or two profiles per year to several profiles for a given week. Additionally, the vertical resolution of the water profiles varied greatly.
For Fish Lake and Lake Wingra, water temperature data were collected from NTL-LTER only from 1996 to 2014 (2012b).

\subsection{Model calibration and evaluation}

Model calibration consisted of two processes: (1) closing the water balance to match simulated and observed water levels and (2) adjusting the minimum water level thickness to match simulated and observed water temperatures for each lake. Water balance for all three lakes was closed using the method described in Sect. 2.3.5 to match measured water levels to known values and to long-term average water levels when elevation information was unknown. Model evaporation rates were not validated; we assume that evaporative water flux and heat flux were properly parameterized by the model. Model parameters were derived from literature values (Table 2). Within the model, the minimum layer thickness sets the limit for how small a water layer can become before it is merged with the smaller of the layers above or below. If the minimum layer thickness is too large, the model may not have the desired resolution to accurately capture changes in temperature and density that occur over small changes in depth. To calibrate this parameter, the minimum layer thickness was varied from 0.05 to $0.5 \mathrm{~m}$ in intervals of $0.025 \mathrm{~m}$ for the period 1995-2000 for all three lakes, similar to the method in Tanentzap et al. (2007) and Weinburger and Vetter (2012). One minimum layer thickness was chosen for all three lakes to keep model formulation and implementation identical among the three lakes, and the final thickness was chosen to be $0.125 \mathrm{~m}$, as it minimized the overall deviation between simulated and observed temperature values for the three lakes.

Three statistical measures were used to evaluate model output against observational data (Table 3): absolute mean error (AME), root mean square error (RMSE), and NashSutcliffe (NS) efficiencies were used to compare simulated and observed temperature values for volumetrically averaged epilimnion temperature, volumetrically averaged hypolimnion temperature, and all individual water temperature measurements for unique depth and sampling time combinations. Simulated and observed values are compared directly, except for aggregation of water temperature measurements to daily intervals where subdaily intervals are available. Water temperatures were evaluated for the full range of available data on each lake.

\subsection{Analysis}

Modeling results were analyzed using linear regression, sequential $t$ test, and Pearson correlation coefficient. Linear regression was used to determine the trend of long-term changes in lake variables. Breakpoints in variables were determined using a piecewise linear regression (Magee et al., 2016; Ying et al., 2015). A sequential $t$ test (Rodionov, 2004; Rodionov and Overland, 2005) was used to detect abrupt 
Table 3. Absolute mean error (AME), root mean square error (RMSE), and Nash-Sutcliffe efficiency (NS) for water temperature variables on Lake Mendota, Lake Wingra, and Fish Lake. $n$ indicates the number of measurements; NA represents errors that cannot be determined because Lake Wingra is a polymictic lake and does not have an epilimnion or hypolimnion.

\begin{tabular}{|c|c|c|c|c|c|c|c|c|c|c|c|c|}
\hline \multirow[b]{2}{*}{ Variable } & \multicolumn{4}{|c|}{ Lake Mendota } & \multicolumn{4}{|c|}{ Fish Lake } & \multicolumn{4}{|c|}{ Lake Wingra } \\
\hline & $n$ & AME & RMSE & NS & $n$ & AME & RMSE & NS & $n$ & AME & RMSE & NS \\
\hline $\begin{array}{l}\text { Epilimnetic } \\
\text { temperature } \\
\left({ }^{\circ} \mathrm{C}\right)\end{array}$ & 3239 & 0.69 & 0.3 & 0.99 & 263 & 1.23 & 1.45 & 0.95 & NA & NA & NA & NA \\
\hline $\begin{array}{l}\text { Hypolimnetic } \\
\text { temperature } \\
\left({ }^{\circ} \mathrm{C}\right)\end{array}$ & 3239 & 1.04 & 0.53 & 0.96 & 263 & 1.63 & 1.94 & 0.92 & NA & NA & NA & NA \\
\hline $\begin{array}{l}\text { Temperature at } \\
1 \mathrm{~m} \text { interval } \\
\left({ }^{\circ} \mathrm{C}\right) \text { : overall } \\
\text { range of values } \\
\text { for depths }\end{array}$ & 85566 & $0.5-1.56$ & $0.25-0.75$ & $0.95-0.99$ & 5522 & $0.85-1.93$ & $1.98-2.42$ & $0.85-0.91$ & 1897 & $0.63-0.85$ & $0.41-0.96$ & 0.99 \\
\hline
\end{tabular}

changes in the mean value of lake variables. The variables were tested on data with trends removed using a threshold significance level of $p=0.05$, a Huber weight parameter of $h=2$, and a cut-off length of $L=10$ years. Coherence of lake variables (Magnuson et al., 1990) for each lake and between lake pairs was determined with a Pearson correlation coefficient (Baron and Caine, 2000). The three lakes were paired to compare coherence of lake variables with surface area difference (Mendota/Fish pair), depth differences (Fish/Wingra pair), and both surface area and depth differences (Mendota/Wingra). Additionally, temperature, stratification, and heat flux pair variables for all three lakes are correlated to air temperature and wind speed drivers, ice date and durations, and temperature, stratification, and heat flux variables within each lake.

To determine the sensitivity of lake water temperature and stratification in response to air temperature and wind speed, we perturbed these drivers across the range of -10 to $+10{ }^{\circ} \mathrm{C}$ in $1{ }^{\circ} \mathrm{C}$ temperature increments and 70 to $130 \%$ of the historical value in $5 \%$ increments, respectively. For each scenario, meteorological inputs remained the same as for the original simulation and snowfall (rainfall) conversion if the air temperature scenarios increased (decreased) above $0^{\circ} \mathrm{C}$. Similarly, the water balance and water clarity are maintained so that the long-term values in both lakes matches the historical record. This limits our analysis, as it may exclude changes in water temperatures as a result of increased evapotranspiration, increased precipitation, or altered water clarity under future climate scenarios. Inflow temperatures are recalculated for each lake to account for increases or decreases in temperature because of air temperature changes.

\section{Results}

\subsection{Changes in air temperature and wind speed}

Yearly average air temperatures $\left(+0.145^{\circ} \mathrm{Cdecade}^{-1}\right.$; $p<0.01$ ) and seasonal air temperatures (winter: $+0.225^{\circ} \mathrm{C}$ decade $^{-1}$; spring $+0.165^{\circ} \mathrm{C} \mathrm{decade}^{-1}$; summer $+0.081^{\circ} \mathrm{Cdecade}^{-1} ;$ fall $\left.+0.110^{\circ} \mathrm{Cdecade}^{-1} ; p<0.05\right)$ increased from 1911 to 2014 (Fig. 2a). Additionally, yearly average air temperatures, but not seasonal temperatures, showed a significant change in slope occurring in 1981 based on a breakpoint analysis and an $F$ test at a 0.05 significance level (Magee et al., 2016), and summer air temperatures showed three significant abrupt changes in mean value (Fig. 2a). Yearly $\left(-0.073 \mathrm{~m} \mathrm{~s}^{-1}\right.$ decade $\left.^{-1} ; p<0.01\right)$ and seasonal average (winter: $-0.083 \mathrm{~m} \mathrm{~s}^{-1}$ decade $^{-1}$; spring $-0.071 \mathrm{~m} \mathrm{~s}^{-1}$ decade $^{-1}$; summer: $-0.048 \mathrm{~m} \mathrm{~s}^{-1}$ decade $^{-1}$; fall: $-0.088 \mathrm{~m} \mathrm{~s}^{-1}$ decade $\left.^{-1} ; p<0.01\right)$ wind speeds decreased from 1911 to 2014 (Fig. 2b). A change in air temperatures also occurred in the 1980s in central Europe (Woolway et al., 2017b), which may indicate that changes in air temperature were a global phenomenon rather than local occurrence. Significant shifts $(p<0.01)$ in the mean occurred in the mid-1990s for all seasons, but there were no changes in rate of wind speed decreases.

\subsection{Model evaluation}

Simulated temperatures agreed well with observations for all three lakes (Fig. 3, Table 3). The model was validated with all available data for all three lakes during the period 19112014. AMEs and RMSEs for all variables were low and less than the standard deviations. NS efficiencies of the daily time bases were high $(>0.85)$ and most above 0.90 , indicating high model accuracy. 

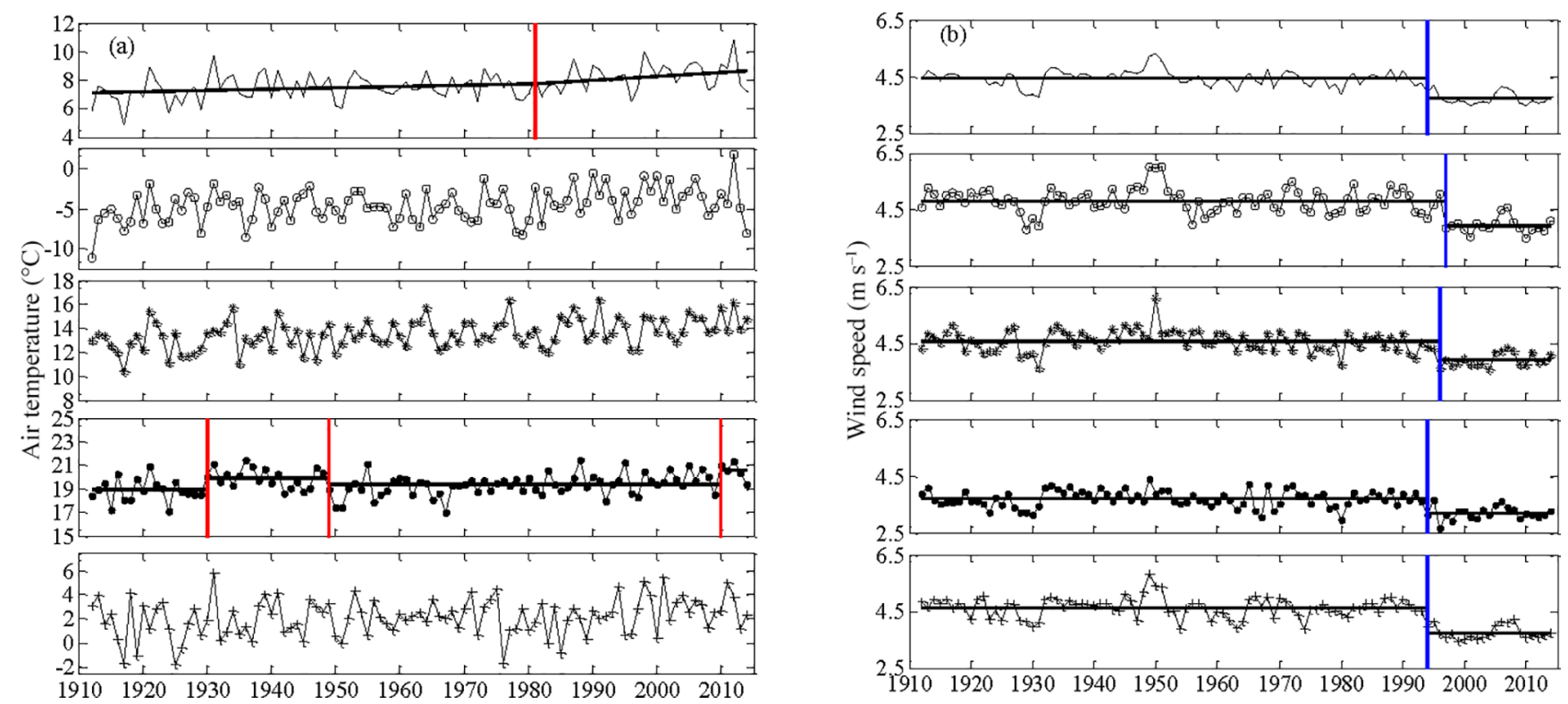

Figure 2. Yearly (solid lines), winter (open circles), spring (asterisks), summer (solid circles), and fall (crosses) (a) air temperature and (b) wind speeds for Madison, WI, USA. The red line in the yearly air temperature figure represents a breakpoint in the trend of average air temperature increase from 0.081 to $0.334{ }^{\circ} \mathrm{C} \mathrm{decade}^{-1}$ occurring in 1981 . Red lines in the summer air temperature figure represent abrupt changes in average summer air temperature occurring in 1930,1949, and 2010. Blue lines in the wind speed figures represent abrupt changes in yearly wind speed change in 1994, winter wind speed in 1997, spring wind speed in 1996, summer wind speed in 1994, and fall wind speed in 1994.

Table 4. Trends and in-lake physical variables for the three studied lakes from 1911 to 2014 . Trends are represented as units decade ${ }^{-1}$. NA indicates data that are not available.

\begin{tabular}{llll}
\hline & Lake Mendota & Fish Lake & Lake Wingra \\
\hline Summer epilimnetic temperature $\left({ }^{\circ} \mathrm{C}\right)$ & $+0.069^{* *}$ & $+0.138^{*}$ & $+0.079^{*}$ \\
Summer hypolimnetic temperature $\left({ }^{\circ} \mathrm{C}\right)$ & $-0.131^{*}$ & $-0.083^{*}$ & NA \\
Stratification onset (days) & 1.15 days earlier* & 0.81 days earlier* & NA \\
Fall overturn (days) & 1.18 days later* & 1.05 days later* & NA \\
Stratification duration (days) & $+2.68^{*}$ & $+1.86^{*}$ & NA \\
Hypolimnetic heating $\left({ }^{\circ} \mathrm{C}\right)$ & $-0.011^{*}$ & $-0.0011^{*}$ & NA \\
Summer Schmidt stability number $\left(\mathrm{J} \mathrm{m}^{-2}\right)$ & $+11.7^{*}$ & $+1.44^{*}$ & no trend \\
Net shortwave flux $\left(\mathrm{W} \mathrm{m}^{-2}\right)$ & no trend & no trend & no trend \\
Net longwave flux $\left(\mathrm{W} \mathrm{m}^{-2}\right)$ & $-0.585^{*}$ & $-0.580^{*}$ & $-0.459^{*}$ \\
Sensible heat flux $\left(\mathrm{W} \mathrm{m}^{-2}\right)$ & $+0.410 *$ & $+0.365 *$ & $+0.565 *$ \\
Latent heat flux $\left(\mathrm{W} \mathrm{m}^{-2}\right)$ & no trend & no trend & no trend \\
Net heat flux $\left(\mathrm{W} \mathrm{m}{ }^{-2}\right)$ & no trend & no trend & no trend \\
\hline
\end{tabular}

* indicates significance to $p<0.05,{ }^{* *}$ indicates significance to $p<0.1$ using a $t$ test.

\subsection{Summer water temperatures}

Lake Mendota and Lake Wingra had similar increasing epilimnetic water temperature trends, while Fish Lake had a larger increase (Table 4). All three lakes have statistically significant $(p<0.01)$ abrupt changes in mean epilimnion temperatures over the study period. For Lake Mendota, a change occurs after 1930 from 22.09 to $22.99^{\circ} \mathrm{C}$. For Fish Lake, three changes were detected: after 1934, from 21.68 to $22.50^{\circ} \mathrm{C}$; after 1995 , from 22.50 to $24.26^{\circ} \mathrm{C}$; after 2008 , from 24.26 to $22.14^{\circ} \mathrm{C}$. Lake Wingra has an abrupt change after 1930 from 23.13 to $24.02^{\circ} \mathrm{C}$. These increases in epilimnetic temperatures are similar to those found for European lakes (Woolway et al., 2017b) in response to regional climate changes, although Woolway et al. (2017b) demonstrated a substantial increase in annually averaged lake surface water temperatures in the late 1980s in response to an abrupt shift in the climate, which is not apparent in epilimnion water 

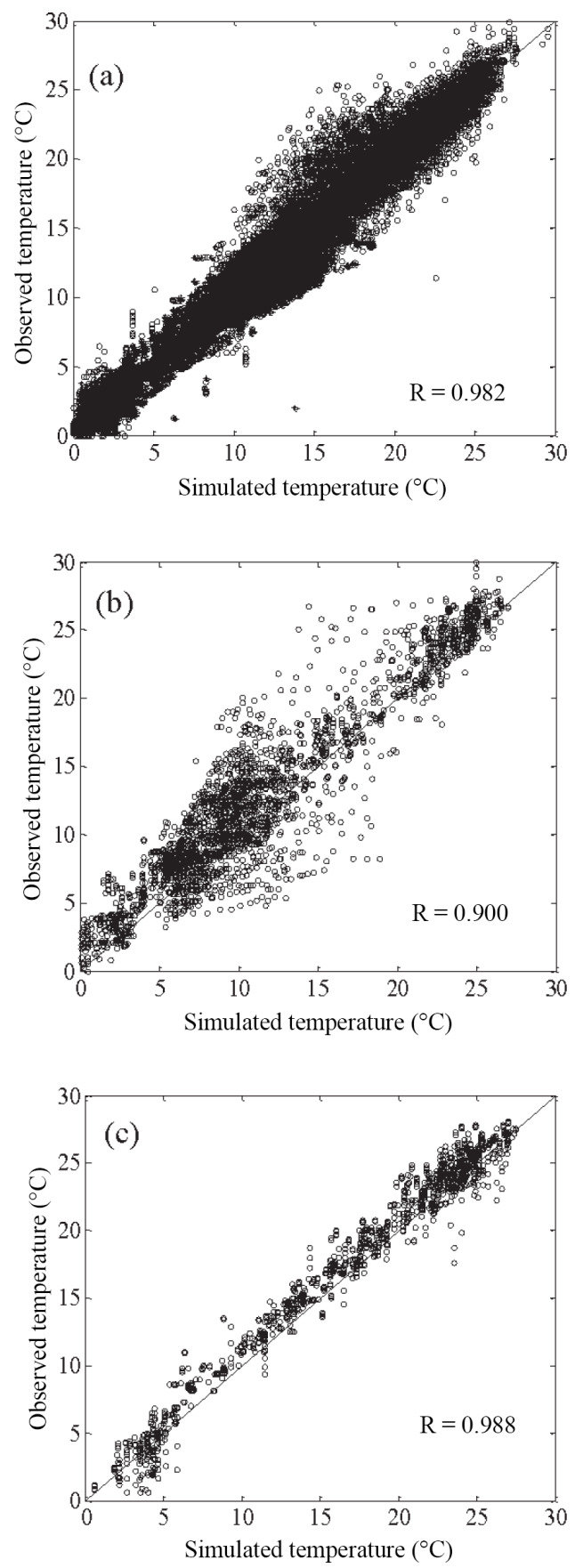

Figure 3. Comparison of observed and simulated water temperatures for (a) Lake Mendota, (b) Fish Lake, and (c) Lake Wingra. Each point represents one observation vs. simulation pair with a unique date and lake depth.

temperatures for our study lakes. Additionally, Van Cleave et al. (2014) showed a regime shift in July-September Lake Superior surface water temperatures after 1997, driven by El Niño in 1997-1998; however, we do not find a similar regime shift in our study lakes, which may be due to geographi- cal differences in meteorology or morphometric differences from the larger Lake Superior.

Lake Mendota and Fish Lake hypolimnions were defined as $20-25$ and $13-20 \mathrm{~m}$, respectively, based on the long-term bottom depth of the metalimnion. Lake Mendota has a larger decrease in hypolimnetic temperature than Fish Lake (Table 4), and neither has an abrupt change in temperature nor a significant breakpoint in linear trend during the study period (Fig. 4). Change in summer (15 July-15 August) hypolimnetic heating was an order of magnitude larger for Mendota than for Fish Lake (Table 4).

\subsection{Stratification and stability}

We characterize summer stratification by stratification onset, fall overturn, and duration of stratification (Fig. 5). Onset of stratification and fall turnover were defined as the day when the surface-to-bottom temperature difference was greater than (for stratification) or less than (for overturn) $2{ }^{\circ} \mathrm{C}$ (Robertson and Ragotzkie, 1990). Lake Wingra experienced only short-term stratification (timescale of days-weeks) and is excluded from this analysis.

Lake Mendota has larger trend in earlier stratification onset, fall overturn, and stratification duration than Fish Lake (Table 4), with most of the difference in stratification duration caused by larger change in stratification onset date for Lake Mendota. For both lakes, a significant $(p<0.01)$ shift in onset date occurred at similar times, with a shift to 13.3 days earlier for Lake Mendota after 1994 and 15.1 days earlier for Fish Lake after 1993. No change in trend occurred for stratification onset or overturn, but stratification duration shifted from +0.067 to +4.5 days decade ${ }^{-1}$ after 1940 for Lake Mendota and from -0.19 days decade ${ }^{-1}$ to +9.6 days decade ${ }^{-1}$ after 1981 for Fish Lake (Fig. 5).

We quantify resistance to mechanical mixing with a Schmidt number (Idso, 1973). Lake Mendota showed greater stability in general than Fish Lake (Fig. 6) and had a larger trend of change than Fish Lake (Table 4), possibly due to a larger change in stratification and hypolimnion temperature, increasing stability. There was no significant abrupt shift or change in trend for any of the three lakes during the study period.

\subsection{Surface heat fluxes}

Modeled surface heat fluxes included net shortwave, net longwave, sensible heat, latent heat, and total heat fluxes (Fig. 7). Magnitudes of shortwave, longwave, and sensible heat fluxes are similar for all three lakes, but Lake Wingra has a larger magnitude of both latent and net heat fluxes. Net longwave is negative for all three lakes and increased in magnitude (Table 4), and sensible heat flux decreased in magnitude (it became less negative; Table 4). There is no significant trend in other surface heat flux variables. Lake Wingra has a much smaller change in trend for longwave radiation 

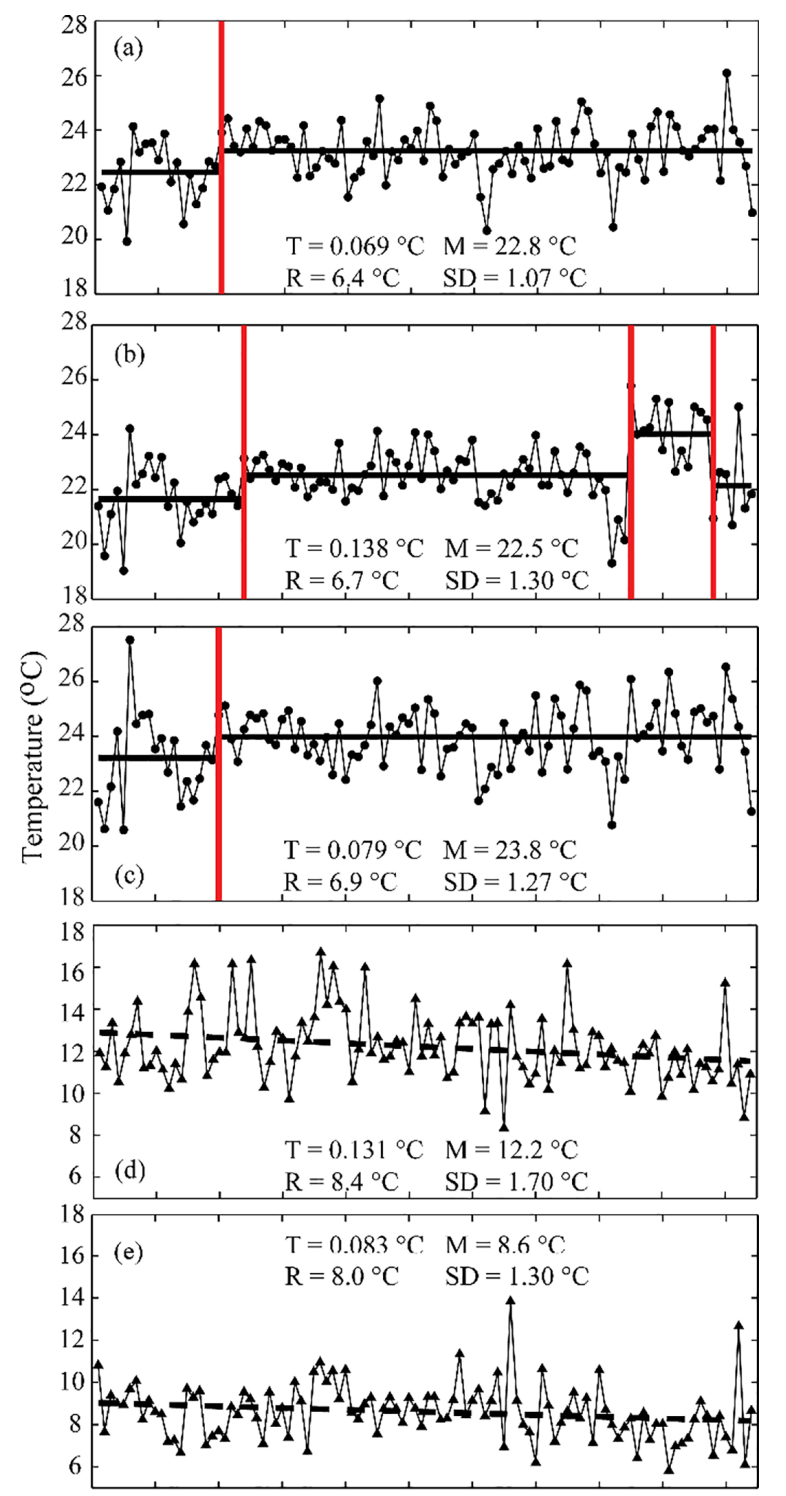

19101920193019401950196019701980199020002010

Figure 4. Mean summertime (15 July-15 August) epilimnetic temperatures for (a) Lake Mendota, (b) Fish Lake, and (c) Lake Wingra, and mean summertime (15 July-15 August) hypolimnetic temperatures for (d) Lake Mendota and (e) Fish Lake. In panels (a), (b), and (c), solid red lines represent statistically significant $(p<0.05)$ locations of abrupt changes in epilimnion temperatures and solid lines represent mean temperatures for each period. In panels (d) and (e), dashed lines represent the long-term trend over the period 1911-2014. $T$ is the trend of water temperature change per decade, $R$ is the range of temperatures, $\mathrm{M}$ is the mean temperature, and SD is the standard deviation in temperatures for the study period. Epilimnion was defined as $0-10 \mathrm{~m}$ depth for Mendota, 0$5 \mathrm{~m}$ for Fish, and the whole water column for Wingra based on surface mixed layer depth calculated using LakeAnalyzer (Read et al., 2011).
Table 5. Correlation coefficients for lake pairs of simulated openwater lake variables. NA indicates data that are not available.

\begin{tabular}{lrrr}
\hline & \multicolumn{3}{c}{ Lake pair } \\
\cline { 2 - 4 } Lake variable & $\begin{array}{r}\text { Mendota/ } \\
\text { Fish }\end{array}$ & $\begin{array}{r}\text { Wingra/ } \\
\text { Fish }\end{array}$ & $\begin{array}{r}\text { Mendota/ } \\
\text { Wingra }\end{array}$ \\
\hline Epilimnion temperature & 0.601 & 0.747 & 0.804 \\
Hypolimnion temperature & 0.474 & $\mathrm{NA}$ & $\mathrm{NA}$ \\
Stratification onset & 0.262 & $\mathrm{NA}$ & $\mathrm{NA}$ \\
Fall overturn & 0.388 & $\mathrm{NA}$ & $\mathrm{NA}$ \\
Schmidt stability number & 0.827 & 0.405 & 0.346 \\
Net shortwave flux & 0.995 & 0.925 & 0.922 \\
Net longwave flux & 0.993 & 0.969 & 0.967 \\
Sensible heat flux & 0.965 & 0.887 & 0.893 \\
Latent heat flux & 0.989 & 0.977 & 0.984 \\
Net heat flux & 0.722 & 0.630 & 0.532 \\
\hline
\end{tabular}

than Mendota or Fish, but a larger change in trend for sensible heat flux, indicating that depth likely influences the response of those heat fluxes to air temperature and wind speed changes.

\subsection{Coherence between lake pairs}

Pearson correlations for all variables and lake pairs are significant (Table 5). Shortwave, longwave, sensible, and latent heat fluxes show high correlation for lake pairs, suggesting that morphometry has little impact on variability among lakes. Similarly, epilimnion temperatures have high temporal coherence. However, Fish Lake pairs have lower correlations, which may be a result of changes to lake depth (Krohelski et al., 2002) compared to stable water levels in Mendota and Wingra. Low coherence between the Mendota/Fish pair for hypolimnion temperature and stratification dates suggests that fetch differences impact variability. Stability, however, is lower for pairs with Lake Wingra, indicating that lake depth plays a role in temporal coherence of stability. Similarly, Lake Wingra pairs have lower coherence of net heat flux although the coherence of heat flux components is relatively high. Depth may be influencing a non-linear response of net heat flux that is not present in the components of the flux.

\subsection{Correlations between lake variables}

Generally, direction and magnitude of Pearson correlation between lake variables are similar for each of the three lakes; however, there are some notable exceptions (Fig. 8). Iceoff dates are significantly correlated with stratification onset dates and hypolimnetic temperature on Fish Lake, but those correlations do not exist for Lake Mendota. Stratification onset is significantly correlated with hypolimnetic temperature and stability in Lake Mendota but not significantly correlated on Fish Lake. Summer air temperatures are more highly correlated with stability than summer wind speed for Lake Men- 


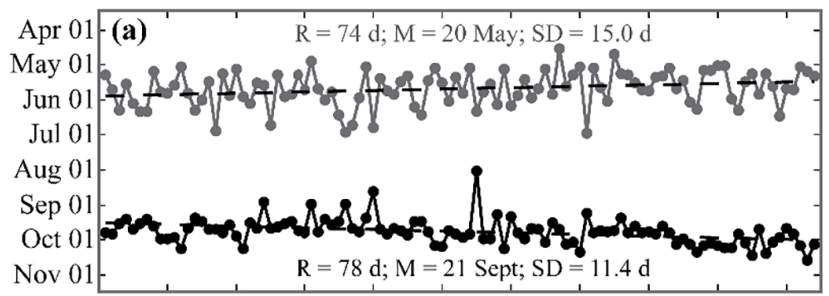

19101920193019401950196019701980199020002010

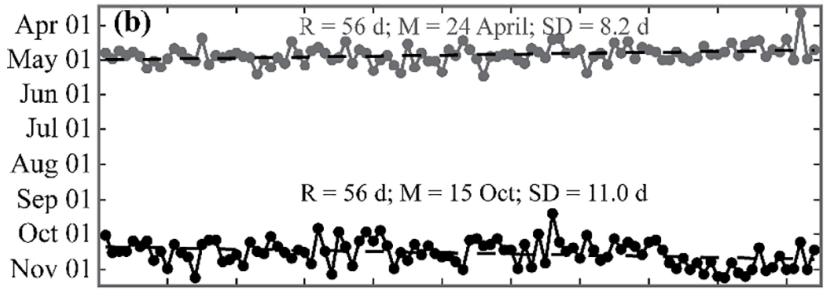

19101920193019401950196019701980199020002010

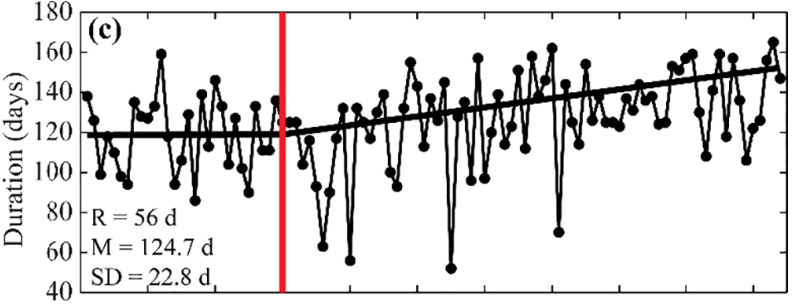

19101920193019401950196019701980199020002010

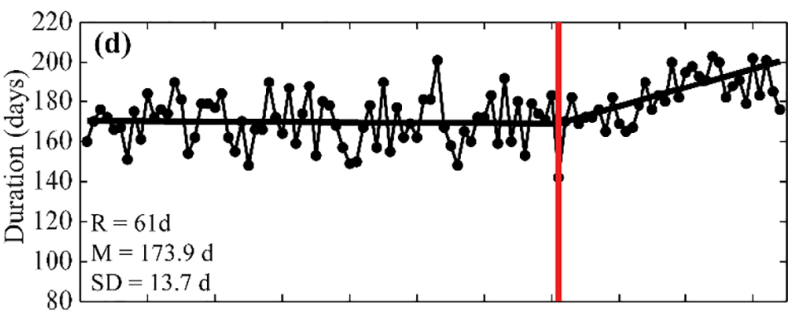

19101920193019401950196019701980199020002010

Figure 5. Stratification onset (gray) and overturn (black) dates for (a) Lake Mendota and (b) Fish Lake. Stratification duration for (c) Lake Mendota and (d) Fish Lake. Dark circles are modeled results and dashed lines denote the trend line for the 104-year period. In panels (a) and (b), dashed lines represent the long-term trend in stratification onset and overturn dates. In panels (c) and (d), solid red lines represent the timing of a statistically significant $(p<0.01)$ change in trend and solid black lines represent the trend during the periods. $R$ is the range of onset, overturn, or duration; $\mathrm{M}$ is the mean date for onset, overturn, or duration length; and SD is the standard deviation in dates for the study period.

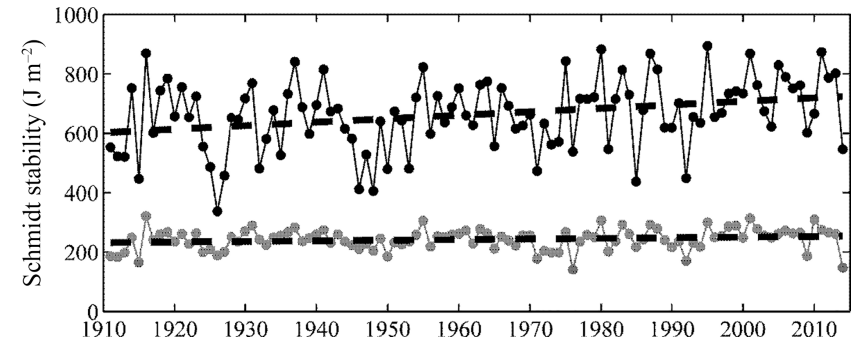

Figure 6. Yearly average summertime (15 July-15 August) Schmidt stability values for Lake Mendota (black) and Fish Lake (gray). Dashed lines represent the long-term trend for each lake.

dota and Fish Lake, but the opposite is true for Lake Wingra, where summer air temperature is not significantly correlated. Additionally, hypolimnion temperature is more highly correlated with stability in Lake Mendota, whereas epilimnion temperature is more highly correlated with stability in Fish Lake.

\subsection{Sensitivity to changes in air temperature and wind speed}

Responses of simulated stratification onset, fall overturn, and hypolimnetic temperature to air temperature and wind speed perturbation scenarios for Lake Mendota and Fish Lake are discussed in the following. Other variables are omitted for brevity and Lake Wingra did not experience prolonged stratification under any sensitivity scenarios, so they are excluded from the analysis. In our analysis, we refer to the "base case"

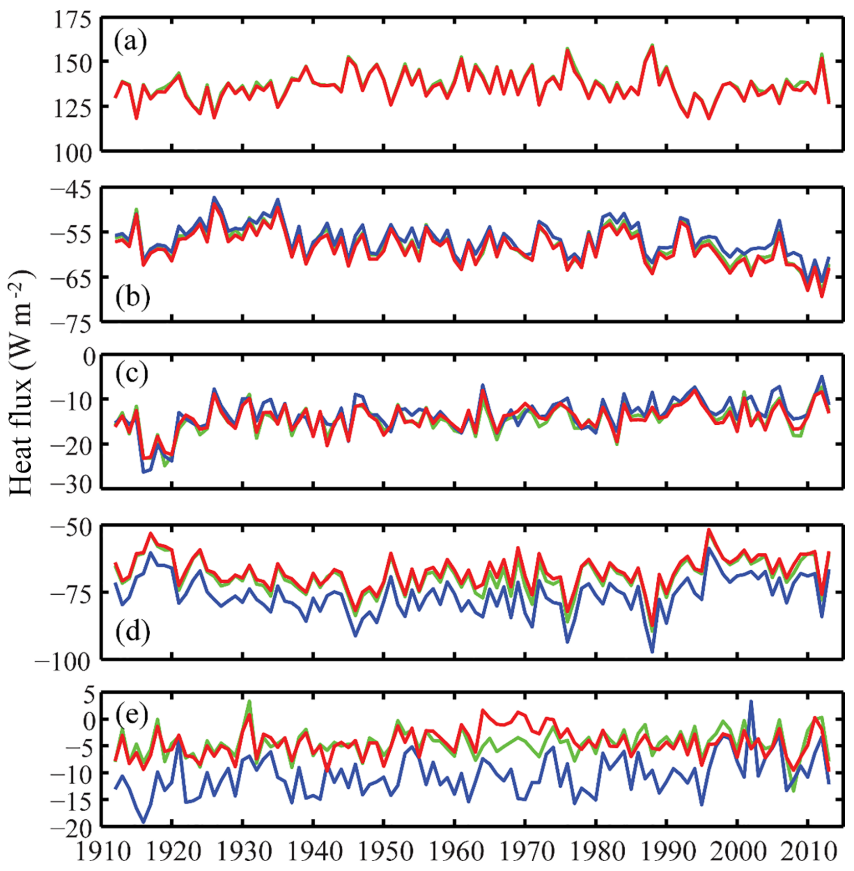

Figure 7. Yearly average (a) radiation flux, (b) longwave radiative flux, (c) sensible heat flux, (d) latent heat flux, and (e) total heat flux at the lake surface for Lake Mendota (solid black line), Fish Lake (black dashed line), and Lake Wingra (solid gray line). Trends and abrupt changes for heat fluxes are not shown on the plots for clarity. 


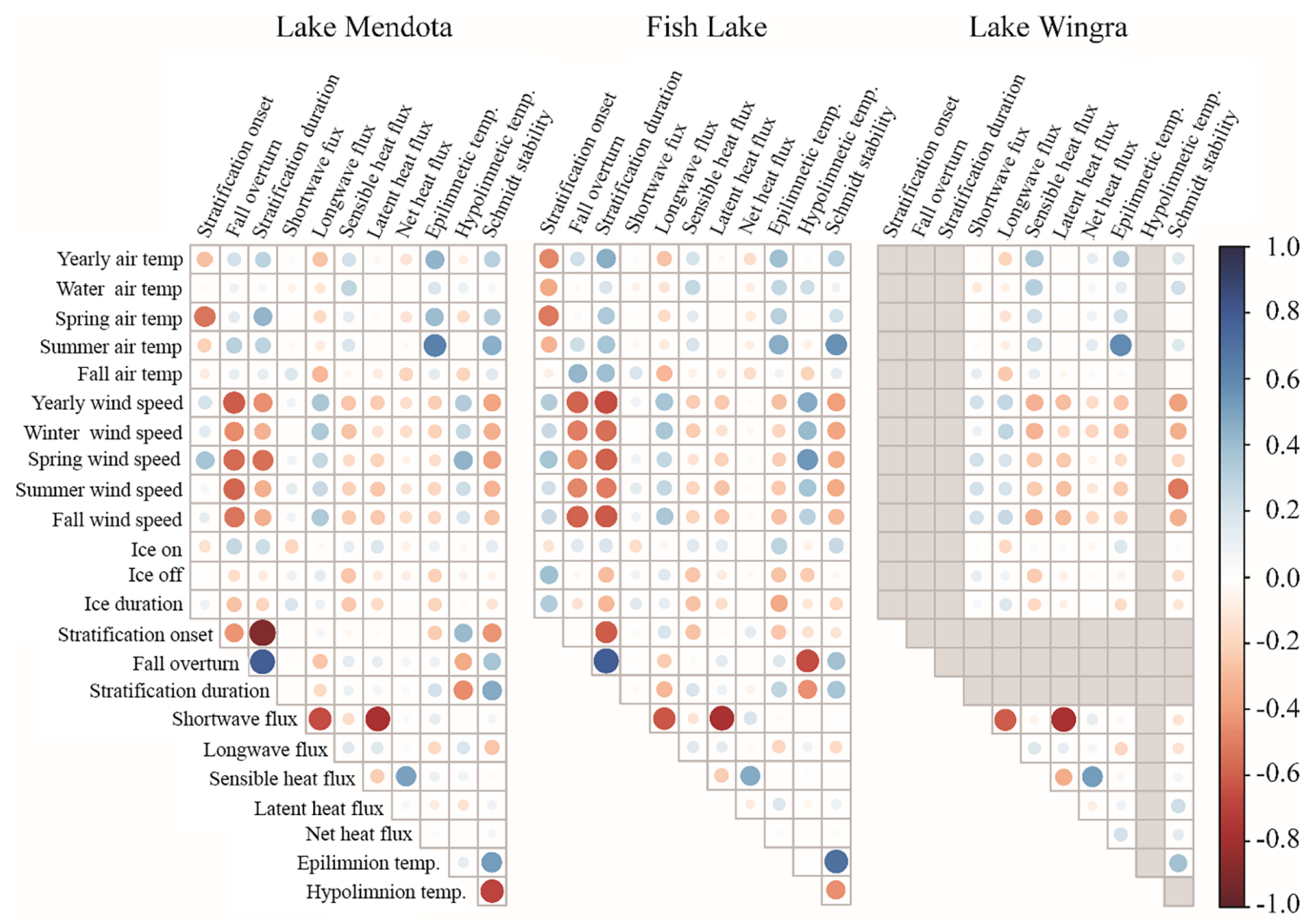

Figure 8. Plots of Pearson correlation coefficients among climate (air temperature and wind speed) variables and lake variables for the three study lakes.

as the meteorological values that represent the historical period from 1911 to 2014 and refer to perturbations in air temperature and wind speed from that base case.

Stratification onset generally occurs earlier on Fish Lake than Lake Mendota for all scenarios (Fig. 9). Simulations show that the response of median onset dates to changes in air temperature is the same for both increases and decreases from the base case $\left(-2.0\right.$ days $\left.{ }^{\circ} \mathrm{C}^{-1}\right)$ for Lake Mendota, but for Fish Lake the magnitude of change is larger for air temperature decreases $\left(-1.5\right.$ days ${ }^{\circ} \mathrm{C}^{-1}$ for temperature increases and +2.7 days ${ }^{\circ} \mathrm{C}^{-1}$ for temperature decreases). Variability in Lake Mendota onset remains consistent across scenarios but decreases for Fish Lake as air temperatures increase. This may be from interaction between ice cover and stratification onset on Fish Lake but not on Lake Mendota. For Lake Mendota, stratification onset dates have a larger change for wind speed increases than decreases $(-3.4$ days $\left(\mathrm{m} \mathrm{s}^{-1}\right)^{-1}$ for decreases and +10.5 days $\left(\mathrm{m} \mathrm{s}^{-1}\right)^{-1}$ for wind speed increases), as is the case for Fish Lake (-3.6 days $\left(\mathrm{m} \mathrm{s}^{-1}\right)^{-1}$ for decreases and +8.1 days $\left(\mathrm{m} \mathrm{s}^{-1}\right)^{-1}$ for wind speed increases). Variability in onset dates decreases with lower wind speeds and increases with higher wind speeds.

Fall overturn typically occurs slightly early on Lake Mendota than on Fish Lake for all scenarios (Fig. 10). For Lake Mendota, stratification overturn dates change at a rate of +0.68 days ${ }^{\circ} \mathrm{C}^{-1}$ with positive and negative perturbations in temperature, while Fish Lake has a larger change for air temperature increases $\left(+1.81\right.$ days ${ }^{\circ} \mathrm{C}^{-1}$ for temperature increases and -0.77 days ${ }^{\circ} \mathrm{C}^{-1}$ for temperature decreases) from the historical condition. Standard deviation in overturn dates decreased slightly for Lake Mendota as air temperature increased but remained consistent for Fish Lake. For stratification overturn dates on Lake Mendota, the change is +13.9 days $\left(\mathrm{m} \mathrm{s}^{-1}\right)^{-1}$ for wind speed decreases and -17.1 days $\left(\mathrm{m} \mathrm{s}^{-1}\right)^{-1}$ for wind speed increases. For Fish Lake, the change is +16.4 days $\left(\mathrm{m} \mathrm{s}^{-1}\right)^{-1}$ for wind speed decreases and -8.5 days $\left(\mathrm{m} \mathrm{s}^{-1}\right)^{-1}$ for wind speed increases. Like onset dates, variability in overturn dates decreases with lower wind speeds and increases with higher wind speeds.

For both lakes, increases in air temperature increase hypolimnetic temperatures, while decreases in wind speed decrease temperatures (Fig. 11). Simulations show that the response of median hypolimnetic temperatures to changes in air temperatures is consistent for Lake Mendota $\left(+0.18^{\circ} \mathrm{C}_{\text {hypolimnion }} \mathrm{C}_{\text {air temperature }}^{-1}\right)$ for both increases and decreases from the base case but not so for Fish Lake $\left(+0.25^{\circ} \mathrm{C}_{\text {hypolimnion }} \mathrm{C}_{\text {air temperature }}^{-1}\right.$ for air temperature increases and $-0.18^{\circ} \mathrm{C}_{\text {hypolimnion }} \mathrm{C}_{\text {air temperature for air tem- }}^{-1}$ perature decreases). Standard deviations under varying air 

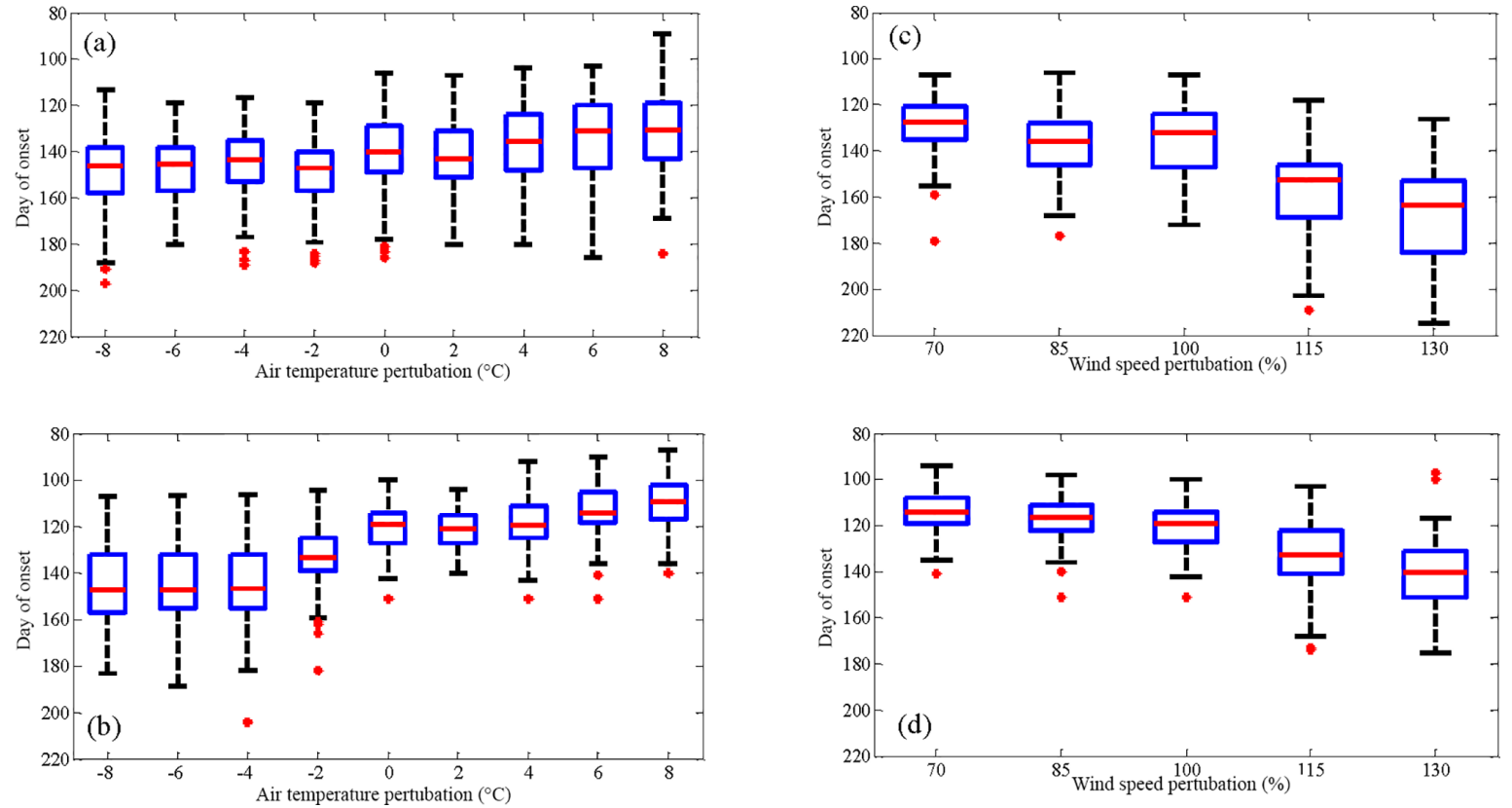

Figure 9. Day of stratification onset under select air temperature perturbation scenarios for (a) Lake Mendota and (b) Fish Lake and day of stratification onset under select wind speed perturbation scenarios for (c) Lake Mendota and (d) Fish Lake. The box represents the 25th and 75 th quartiles and the central line is the median value. The whiskers extend to the minimum and maximum data points in the cases where there are no outliers, which are plotted individually.
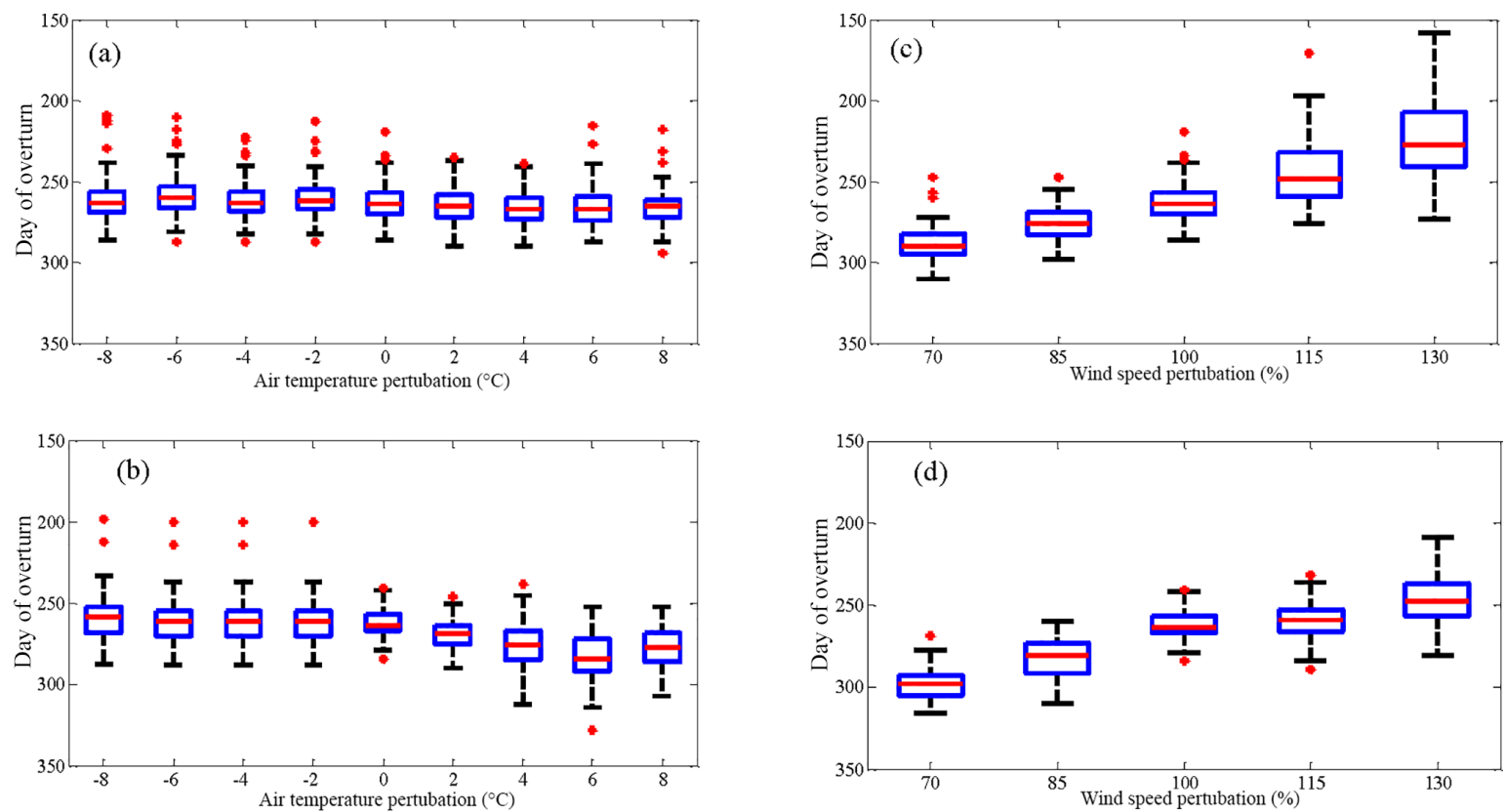

Figure 10. Day of stratification overturn under select air temperature perturbation scenarios for (a) Lake Mendota and (b) Fish Lake and day of stratification overturn under select wind speed perturbation scenarios for (c) Lake Mendota and (d) Fish Lake. The box represents the 25 th and 75 th quartiles and the central line is the median value. The whiskers extend to the minimum and maximum data points in the cases where there are no outliers, which are plotted individually. 

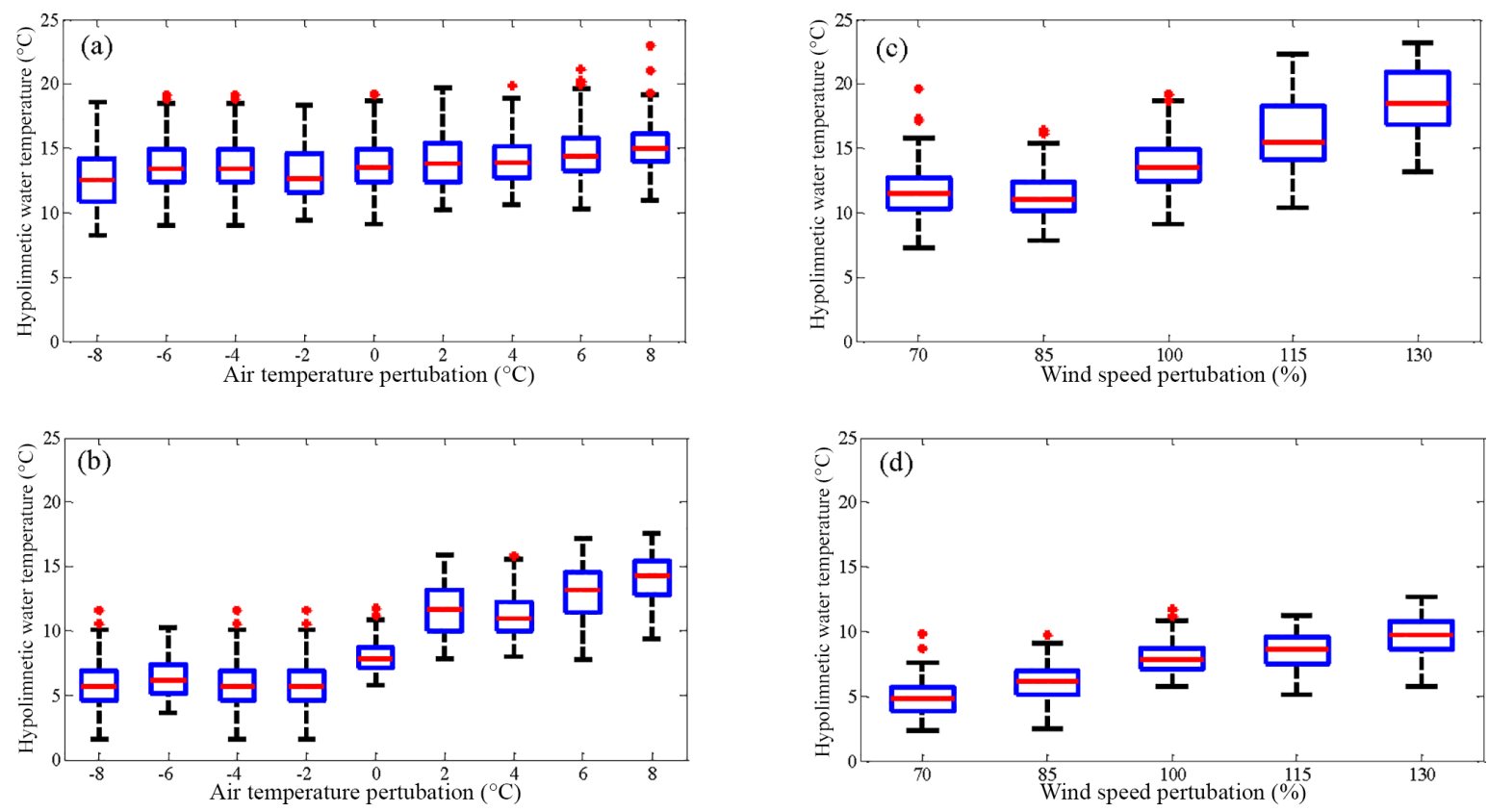

Figure 11. Hypolimnetic water temperatures under select air temperature perturbation scenarios for (a) Lake Mendota and (b) Fish Lake and hypolimnetic water temperatures under select wind speed perturbation scenarios for (c) Lake Mendota and (d) Fish Lake. The box represents the 25 th and 75th quartiles and the central line is the median value. The whiskers extend to the minimum and maximum data points in the cases where there are no outliers, which are plotted individually.

temperature scenarios remain consistent for both lakes. Hypolimnion temperatures change inconsistently with increases and decreases in wind speed for both lakes. For Lake Mendota, the change is $-1.1^{\circ} \mathrm{C}\left(\mathrm{m} \mathrm{s}^{-1}\right)^{-1}$ for decreases and $+1.8^{\circ} \mathrm{C}\left(\mathrm{m} \mathrm{s}^{-1}\right)^{-1}$ for wind speed increases. For Fish Lake, the change is $-1.2^{\circ} \mathrm{C}\left(\mathrm{m} \mathrm{s}^{-1}\right)^{-1}$ for decreases and $+0.8^{\circ} \mathrm{C}$ $\left(\mathrm{m} \mathrm{s}^{-1}\right)^{-1}$ for wind speed increases. Variability decreases for lower wind speeds in Lake Mendota but remains constant for Fish Lake.

\section{Discussion}

\subsection{Model performance and comparison}

The DYRESM-WQ-I model reliably simulated water temperatures over long-term (1911-2014) simulations (Fig. 3, Table 4). Generally, simulated temperatures were lower than observed values. Some may be attributed to timing of observations, which in most instances occur during midday, when water temperatures may be slightly higher than daily averages, as output from the model. Slight deviation is also expected due to averaging of air temperature and wind speeds. In general, thermocline depths were within $1 \mathrm{~m}$ of observed values, but some years differ by as much as $2.5 \mathrm{~m}$, contributing additional error in water temperature comparison for depths near the thermocline.

The performance of the DYRESM-WQ-I model was within those of other studies. Perroud et al. (2009) per- formed a comparison of one-dimensional lake models on Lake Geneva, and RMSEs for water temperatures were as high as $2{ }^{\circ} \mathrm{C}$ for the Hostetler model (Hostetler and Bartlein, 1990), $1.7^{\circ} \mathrm{C}$ for DYRESM (Tanentzap et al., 2007), $2^{\circ} \mathrm{C}$ for SIMSTRAT, and $4{ }^{\circ} \mathrm{C}$ for the Freshwater Lake Model (FLake) (Golosov et al., 2007; Kirillin et al., 2012). Similar to this study, errors in the upper layers were lower than those in the bottom of the water column (Perroud et al., 2009). Fang and Stefan (1996) gave standard errors of water temperature of $1.37^{\circ} \mathrm{C}$ for the open-water season and $1.07^{\circ} \mathrm{C}$ for the total simulation period for Thrush Lake, MN, similar to those here. Nash-Sutcliffe efficiency coefficients for all three study lakes were within the ranges found in Yao et al. (2014) for the Simple Lake Model (SIM; Jöhnk et al., 2008), Hostetler, Minlake (Fang and Stefan, 1996), and General Lake Model (GLM; Hipsey et al., 2014) for Harp Lake, Ontario, Canada, water temperatures.

Model parameters used to characterize the lake hydrodynamics were taken from literature values. These values may be expected to have small variability between lakes; however, previous studies have shown that many of the hydrodynamic parameters are insensitive to changes of $\pm 10 \%$ (Tanentzap et al., 2007). Here, the model was validated against an independent dataset for each lake to determine if the model fits measured data and functions adequately, with errors within the range of those from other studies. Adjustments were made to limit uncertainty and errors associated with changes in location and techniques of meteorological measurements. In- 
flow and outflow measurements were assessed by the USGS for quality assurance and control, but uncertainty for both quantity and water temperature is unknown. The effects of these uncertainties may not be large as the inflow and outflow are small in comparison to lake volume. The combination of uncertainties in parameters and observed data may be high; however, as all parameters and observational methods were kept consistent among the three lakes, the validity of the model in predicting differences among the three lake types is adequate.

The main limitation in the model and resulting simulations is the assumption of one-dimensionality in both the model and field data. Quantifying the uncertainty from this limitation can be difficult (Gal et al., 2014; Tebaldi et al., 2005) Small, stratified lakes generally lack large horizontal temperature gradients (Imberger and Patterson, 1981), allowing the assumption of one-dimensionality to be appropriate. However, short-term deviations in water temperature and thermocline depth may exist due to internal wave activity, especially in larger lakes (Tanentzap et al., 2007), and spatial variations in wind stress can produce horizontal variations in temperature profiles (Imberger and Parker, 1985). To address the role of internal wave activity and benthic boundary layer mixing, the pseudo two-dimensional deep mixing model by Yeates and Imberger (2003) is employed here. This mixing model has been shown to accurately characterize deep mixing that distributes heat from the epilimnion into the hypolimnion, thus weakening stratification, and the rapid distribution of heat entering the top of the hypolimnion from benthic boundary layer mixing, which strengthens stratification (Yeates and Imberger, 2003). Tributary inflows may also contribute to enhanced diffusion due to inflow momentum; however, lakes used in this study are seepage-dominated lakes with little to no tributary contribution, so this phenomenon does not prevent the one-dimensional model from being applicable in this study. This one-dimensional assumption here and corresponding model results may not apply elsewhere for lakes with large inflow volumes.

Additionally, light extinction significantly impacts thermal stratification (Hocking and Straškraba, 1999) and light extinction estimated from Secchi depths can have a large degree of measurement uncertainty (Smith and Hoover, 2000), which may result in uncertainty in water temperatures. To address this uncertainty, where available, we use measured Secchi depth values, which have been shown to improve estimates of the euphotic zone over fixed coefficients (Luhtala and Tolvanen, 2013). Secchi depths were unavailable for portions of the simulation period, and average values for the season were used. Analysis comparing using the method of known Secchi depths to both seasonally varying average Secchi depths and constant Secchi depths for the lakes indicates that seasonally varying averages do not significantly decrease model reliability when compared to year-specific values but do show improvement over constant Secchi depths.

\subsection{Importance of wind speed and other variables}

While many have addressed the importance of changing air temperatures on water temperatures and water quality (e.g., Adrian et al., 2009; Arhonditsis et al., 2004; O'Reilly et al., 2015; Shimoda et al., 2011), fewer have investigated wind speed as a specific driver of changes to lakes (Magee et al., 2016; Kimura et al., 2016; Snortheim et al., 2017). However, results here show that correlations between wind speeds and lake temperature variables are as high as, or higher than, correlations between air temperature and lake temperature variables (Fig. 8), highlighting the importance of considering wind speeds as drivers of lake temperature and stratification changes. For many variables (e.g., stratification dates, epilimnetic temperatures, stability), correlation is opposite for air temperature and wind speed variables, indicating that wind speed increases may offset the effect of air temperature increases, while locations with decreasing wind speeds may experience a greater impact on water temperature and stratification than with air temperature increases alone. This is further supported through sensitivity analysis on stratification onset and overturn (Figs. 9 and 10), which show that, for Madison-area lakes, increasing air temperatures and decreasing wind speeds have a cumulative effect toward earlier stratification onset and later overturn. Other studies have also found that wind speed can be as important as or even more important than air temperature for influencing lake stratification and water temperatures. For example, Woolway et al. (2017a) found that for polymictic Lake Võrtsjärv, wind speed is the key factor on the number of stratified days, and the influence of air temperature increases was minimal; Kerimoglu and Rinke (2013) found that a $30 \%$ increase in wind speed can compensate up to a $5.5 \mathrm{~K}$ increase in air temperature, and Hadley et al. (2014) suggested that the combination of increased air temperature and decreased wind is the primary driver of enhanced stability in Harp Lake since 1979, although no significant change in the timing of onset, breakdown, or duration of stratification was observed. However, for hypolimnetic temperatures, correlations and sensitivity indicate that decreasing wind speeds may cool hypolimnetic temperatures, while increasing air temperatures warm hypolimnetic temperatures. Arvola et al. (2009) showed that hypolimnion temperatures were primarily determined by the conditions that pertained during the previous spring turnover and timing of stratification onset, which is consistent with our results showing significant $(p<0.01)$ correlation between hypolimnion temperatures and wind speed (Fig. 8) but no significant correlation with air temperature or summer conditions. This could explain the conflicting results of previous research showing both warming and cooling trends in different lakes (Gerten and Adrian, 2001). Hindcasted hypolimnion temperatures (Fig. 4) show decreasing trends for Lake Mendota and Fish Lake. Combining the effects of air temperature and wind speed, it suggests that wind speed decreases are a larger driver to hypolimnetic water temperature 
changes than increasing air temperatures for both lakes. This is particularly notable as current research has been dominated by studying air temperature effects and neglecting the role of wind speed changes.

Ultimately, lake warming or cooling may depend on the magnitudes and directions of changes of air temperature, wind speed, and other variables as climatic variables (humidity, cloud cover, solar radiation and water clarity) are important in determining lake water temperatures. Schmid and Köster (2016) demonstrated that $40 \%$ of surface water warming in Lake Zurich was caused by increased solar radiation, and Wilhelm et al. (2006) showed that daily extrema of surface equilibrium temperature responded to shifts in wind speed, relative humidity, and cloud cover in addition to changes in air temperature. However, neither study looked at lakes with seasonal ice cover, which may not account for changes in ice sheet formation and the resulting influence on lake water temperatures (Austin and Colman, 2007). Other studies have demonstrated that ice cover changes do not directly influence summer surface water temperatures (Zhong et al., 2016), in agreement with our modeling results (Fig. 8). Changes in underwater light conditions from increased dissolved organic carbon concentrations combined with reduction in surface wind speeds can result in cooling wholelake average temperatures despite substantial air temperature increases, as was the case for Clearwater Lake, Canada (Tanentzap et al., 2008). Water clarity has seen both increases and decreases since the early 1990s (Rose et al., 2017), with precipitation playing a critical role in year-to-year variability (Rose et al., 2017). Further investigation into the combined effects of these climatic and lake-specific variables is warranted.

\subsection{Role of morphometry on water temperature and stratification}

\subsubsection{Lake depth}

Lake depth plays a key role in determining thermal structure and stratification of the three lakes in this study. Even under the extreme increases in air temperature, Lake Wingra remained polymictic and did not become dimictic like Lake Mendota or Fish Lake. Additionally, Schmidt stability exhibited no trend on the shallow lake, unlike for the deeper two (Table 4). Due to lower heat capacity, shallow lakes respond more directly to short-term variations in the weather (Arvola et al., 2009), and heat can be transferred throughout the water column by wind mixing (Nõges et al., 2011). This was particularly evident in correlations among drivers and lake variables, where air temperature did not have a significant correlation with stability for Lake Wingra, but wind speed was highly correlated. For shallow lakes, wind speed may be a larger driver to temperature structure and stability, with the importance of air temperature increasing with lake depth. Deep lakes have a higher heat capacity so that greater wind speeds are required to completely mix the lake during the summer months, resulting in more temperature stability and higher Schmidt stability values for deeper Lake Mendota and Fish Lake. Our study is consistent with previous research showing mean lake depths can explain the most variation in stratification trends, and lakes with greater mean depths have larger changes in their stability (Kraemer et al., 2015). Overall, Lake Wingra had a larger magnitude of latent and net heat fluxes than the deeper lakes. Diurnal variability in surface temperatures is larger for shallow lakes, promoting increased latent heat fluxes in these lakes (Woo, 2007). This increased response may also explain the larger change in trend for sensible heat flux since Lake Wingra responds more quickly to changes in air temperature and thus has a larger change in sensible heat flux during each day. Interestingly, net heat flux of Lake Wingra is less coherent with the deeper lakes than the deep lakes are with each other. This may be due to the combination of more extreme temperature variability, increasing sensible and latent heat fluxes during the open-water season, and the lower sensitivity of ice cover duration in Lake Wingra compared to the deeper lakes (Magee and $\mathrm{Wu}, 2017$ ). Ice cover significantly reduces heat fluxes at the surface (Jakkila et al., 2009; Leppäranta et al., 2016; Woo, 2007), and larger changes in ice cover duration for Lake Mendota and Fish Lake compared to Lake Wingra would reduce synchrony of heat fluxes among the three lakes.

\subsubsection{Surface area}

Lake surface area impacts the effects of climate changes on water temperatures and stratification. Air temperature is significantly correlated $(p<0.01)$ with epilimnion temperature for all three lakes, as is wind speed $(p<0.05)$. Increasing air temperatures are well documented to increase epilimnetic water temperatures (Livingstone, 2003; Robertson and Ragotzkie, 1990), since air temperature drives heat transfer between the atmosphere and lake (Boehrer and Schultze, 2008; Palmer et al., 2014). However, wind mixing can act as a mechanism of heat transfer (Nõges et al., 2011), and cool the epilimnion through increased surface mixed layer deepening. Decreasing wind speeds may increase epilimnion temperatures above those from air temperature increases alone (Fig. 8). Surface area plays a role in lake-wide average vertical heat fluxes from boundary processes (Wüest and Lorke, 2003), and the model accounts for this by including an effective surface area algorithm to scale transfer of momentum from surface stress based on lake surface area (Yeates and Imberger, 2003). This increases transfer momentum from surface stress and vertical heat transfer for lakes with larger fetch. Accounting for this larger fetch increases mixing and vertical transfer of heat to bottom waters, reducing epilimnion water temperatures (Boehrer and Schultze, 2008) and increasing the rate of lake cooling (Nõges et al., 2011). For this reason, Lake Mendota with the large fetch experiences a smaller increase in epilimnetic water tempera- 
ture compared to Fish Lake (Table 5). Additionally, momentum from surface stress scales linearly with lake area and non-linearly with wind speed (Yeates and Imberger, 2003; see their Eqs. 31 and 33), making momentum from surface stress, and thus mixing, stratification, and hypolimnion temperatures, more variable for lakes with larger fetch and even more variable when wind speed is increased (see Figs. 9-11). Greater variability in momentum and mixing corresponds to larger variability of Schmidt stability for Lake Mendota, with the larger surface area. Greater transfer of momentum in Lake Mendota results in the slightly deeper thermocline for the larger surface area lake $(\sim 10 \mathrm{~m}$ in Lake Mendota and $\sim 6 \mathrm{~m}$ in Fish Lake), which may play a role in filtering the climate signals into hypolimnion temperatures. Low hypolimnetic temperature coherence between Mendota and Fish suggests that lake morphometry plays a role. This result is consistent with other studies that show lake morphometry parameter affects the way temperature is stored in the lake system (Thompson et al., 2005). Increased momentum on Lake Mendota from the larger surface area may also limit the impact of ice-off dates on stratification onset and hypolimnetic temperatures because the lake has ample momentum to sustain mixing events regardless of ice-off dates, while Fish Lake's small surface area limits mixing, making ice-off dates and stratification more highly correlated.

\section{Conclusion}

The combination of increasing air temperatures and decreasing wind speeds in Madison-area lakes resulted in warmer epilimnion temperatures, cooler hypolimnion temperatures, longer stratification, increased stability, and greater longwave and sensible heat fluxes. Increased stratification durations and stability may have lasting impacts on fish populations (Gunn, 2002; Jiang et al., 2012; Sharma et al., 2011), and warmer epilimnion temperatures affect the phytoplankton community (Francis et al., 2014; Rice et al., 2015). Shallow lakes respond more directly to changes in climate, which drives differences in surface heat flux compared to deeper lakes, and wind speed may be a larger driver to temperature structure than air temperatures, with importance of air temperatures increasing as lake depth increases. Larger surface area lakes have greater wind mixing, which influences differences in temperatures, stratification, and stability. Climate perturbations indicate that larger lakes have more variability in temperature and stratification variables than smaller lakes, and this variability increases with greater wind speeds. Most significantly, for all three lakes, wind speed plays a role as large as, or larger than, air temperatures in temperature and stratification variables. This reveals that air temperature increases are not the only climate variable that managers should plan for when planning mitigation and adaptation techniques. Previous research has shown uncertainty in the changes in hypolimnion water temperatures for dimictic lakes; however, the perturbation scenarios indicate that while increasing air temperature always increases hypolimnion temperature, wind speed is a larger driving force, and the ultimate hypolimnion temperature response may be primarily determined by whether the lake experiences an increase or decrease in wind speeds. Understanding this role in the context of three lakes of differing morphometry is important when developing a broader understanding of how lakes will respond to changes in climate. Lake water temperatures play a driving role in chemical and biological changes that may occur under future climate scenarios, and identifying differences in this response across lakes will aid in the understanding of lake ecosystems and provide critical information to guide lake management and adaptation efforts.

Data availability. At last, readers who are interested in accessing the DYRESM code should contact the authors: Chin Wu (chinwu@engr.wisc.edu) or Madeline Magee (mrmagee@wisc.edu).

Competing interests. The authors declare that they have no conflict of interest.

Acknowledgements. The authors acknowledge Yi-Fang Hsieh for assisting in the development of an ice module in the DYRESM-WQ model that was originally provided by David Hamilton. We would like to thank Dale Robertson at Wisconsin USGS and Richard (Dick) Lathrop at Center for Limnology for providing valuable long-term observation data for the three study lakes. In addition, we thank John Magnuson at Center of Limnology for his insightful suggestions and valuable comments regarding climate change on lakes. We also thank the editor and anonymous reviewers for providing helpful comments that have greatly improved the manuscript. Research funding was provided in part by the US National Science Foundation Long-Term Ecological Research Program, University of Wisconsin (UW) Water Resources Institute USGS 104(B) Research Project, and the UW Office of Sustainability SIRE Award Program. In addition, the first author was funded in part by the College of Engineering Grainer Wisconsin Distinguished Graduate Fellowship.

Edited by: Jan Seibert

Reviewed by: five anonymous referees

\section{References}

Adrian, R., O'Reilly, C. M., Zagarese, H., Baines, S. B., Hessen, D. O., Keller, W., Livingstone, D. M., Sommaruga, R., Straile, D., Van Donk, E., Weyhenmeyer, G. A., and Winder, M.: Lakes as sentinels of climate change, Limnol. Oceanogr., 54, 2283-2297, 2009. 
Antenucci, J. and Imerito, A.: The CWR dynamic reservoir simulation model DYRESM, Centre for Water Research, The University of Western Australia, 2003.

Arhonditsis, G. B., Brett, M. T., DeGasperi, C. L., and Schindler, D. E.: Effects of Climatic Variability on the Thermal Properties of Lake Washington, Limnol. Oceanogr., 49, 256-270, 2004.

Arvola, L., George, G., Livingstone, D. M., Järvinen, M., Blenckner, T., Dokulil, M. T., Jennings, E., Aonghusa, C. N., Nõges, P., Nõges, T., and Weyhenmeyer, G. A.: The Impact of the Changing Climate on the Thermal Characteristics of Lakes, in: The Impact of Climate Change on European Lakes, edited by: George, G., 85-101, Springer Netherlands, 2009.

Austin, J. A. and Allen, J.: Sensitivity of summer Lake Superior thermal structure to meteorological forcing, Limnol. Oceanogr., 56, 1141-1154, https://doi.org/10.4319/lo.2011.56.3.1141, 2011.

Austin, J. A. and Colman, S. M.: Lake Superior summer water temperatures are increasing more rapidly than regional air temperatures: A positive ice-albedo feedback, Geophys. Res. Lett., 34, L06604, https://doi.org/10.1029/2006GL029021, 2007.

Baron, J. and Caine, N.: Temporal coherence of two alpine lake basins of the Colorado Front Range, USA, Freshw. Biol., 43, 463-476, https://doi.org/10.1046/j.1365-2427.2000.00517.x, 2000.

Birge, E. A., Juday, C., and March, H. W.: The temperature of the bottom deposits of Lake Mendota; a chapter in the heat exchanges of the lake, Trans. Wis. Acad. Sci. Arts Lett., XXIII, available at: http://digicoll.library.wisc.edu/cgi-bin/ WI/WI-idx ?type $=$ article\&did=WI.WT1927.EABaird\&id=WI. WT1927\&isize=M (last access: 1 October 2015), 1927.

Boehrer, B. and Schultze, M.: Stratification of lakes, Rev. Geophys., 46, 2006RG000210, https://doi.org/10.1029/2006RG000210, 2008.

Breslow, P. B. and Sailor, D. J.: Vulnerability of wind power resources to climate change in the continental United States, Renew. Energy, 27, 585-598, https://doi.org/10.1016/S09601481(01)00110-0, 2002.

Butcher, J. B., Nover, D., Johnson, T. E., and Clark, C. M.: Sensitivity of lake thermal and mixing dynamics to climate change, Clim. Change, 129, 295-305, https://doi.org/10.1007/s10584015-1326-1, 2015.

Carpenter, S. R. and Lathrop, R. C.: Probabilistic Estimate of a Threshold for Eutrophication, Ecosystems, 11, 601-613, https://doi.org/10.1007/s10021-008-9145-0, 2008.

Desai, A. R., Austin, J. A., Bennington, V., and McKinley, G. A.: Stronger winds over a large lake in response to weakening air-to-lake temperature gradient, Nat. Geosci., 2, 855-858, https://doi.org/10.1038/ngeo693, 2009.

Dobiesz, N. E. and Lester, N. P.: Changes in mid-summer water temperature and clarity across the Great Lakes between 1968 and 2002, J. Gt. Lakes Res., 35, 371-384, https://doi.org/10.1016/j.jglr.2009.05.002, 2009.

Fang, X. and Stefan, H. G.: Long-term lake water temperature and ice cover simulations/measurements, Cold Reg. Sci. Technol., 24, 289-304, https://doi.org/10.1016/0165-232X(95)00019-8, 1996.

Ficker, H., Luger, M., and Gassner, H.: From dimictic to monomictic: Empirical evidence of thermal regime transitions in three deep alpine lakes in Austria induced by climate change, Freshw. Biol., 62, 1335-1345, https://doi.org/10.1111/fwb.12946, 2017.

Francis, T. B., Wolkovich, E. M., Scheuerell, M. D., Katz, S. L., Holmes, E. E., and Hampton, S. E.: Shifting Regimes and Changing Interactions in the Lake Washington, USA, Plankton Community from 1962-1994, PLoS ONE, 9, e110363, https://doi.org/10.1371/journal.pone.0110363, 2014.

Gal, G., Imberger, J., Zohary, T., Antenucci, J., Anis, A., and Rosenberg, T.: Simulating the thermal dynamics of Lake Kinneret, Ecol. Model., 162, 69-86, 2003.

Gal, G., Makler-Pick, V., and Shachar, N.: Dealing with uncertainty in ecosystem model scenarios: Application of the singlemodel ensemble approach, Environ. Model. Softw., 61, 360-370, https://doi.org/10.1016/j.envsoft.2014.05.015, 2014.

Gerten, D. and Adrian, R.: Differences in the persistency of the North Atlantic Oscillation signal among lakes, Limnol. Oceanogr., 46, 448-455, https://doi.org/10.4319/lo.2001.46.2.0448, 2001.

Golosov, S., Maher, O. A., Schipunova, E., Terzhevik, A., Zdorovennova, G., and Kirillin, G.: Physical background of the development of oxygen depletion in ice-covered lakes, Oecologia, 151, 331-340, https://doi.org/10.1007/s00442-006-0543-8, 2007.

Gunn, J. M.: Impact of the 1998 El Niño event on a Lake Charr, Salvelinus Namaycush, Population Recovering from Acidification, Environ. Biol. Fishes, 64, 343-351, https://doi.org/10.1023/A:1016058606770, 2002.

Hadley, K. R., Paterson, A. M., Stainsby, E. A., Michelutti, N., Yao, H., Rusak, J. A., Ingram, R., McConnell, C., and Smol, J. P.: Climate warming alters thermal stability but not stratification phenology in a small north-temperate lake, Hydrol. Process., 28, 6309-6319, https://doi.org/10.1002/hyp.10120, 2014.

Hamilton, D. P. and Schladow, S. G.: Prediction of water quality in lakes and reservoirs. Part I - Model description, Ecol. Model., 96, 91-110, https://doi.org/10.1016/S0304-3800(96)00062-2, 1997.

Hamilton, D. P., Magee, M. R., Wu, C. H., and Kratz, T. K.: Ice cover and thermal regime in a dimictic seepage lake under climate change, Inland Waters, in review, 2017.

Hansen, J., Ruedy, R., Sato, M., and Lo, K.: Global surface temperature change, Rev. Geophys., 48, RG4004, https://doi.org/10.1029/2010RG000345, 2010.

Hennings, R. G. and Connelly, J. P.: Average ground-water temperature map, Wisconsin, Wisconsin Geological and Natural History Survey, Madison, Wisconsin, USA, 2008.

Hetherington, A. L., Schneider, R. L., Rudstam, L. G., Gal, G., DeGaetano, A. T., and Walter, M. T.: Modeling climate change impacts on the thermal dynamics of polymictic Oneida Lake, New York, United States, Ecol. Model., 300, 1-11, https://doi.org/10.1016/j.ecolmodel.2014.12.018, 2015.

Hill, J. M. and Kucera, A.: Freezing a saturated liquid inside a sphere, Int. J. Heat Mass Transf., 26, 1631-1637, https://doi.org/10.1016/S0017-9310(83)80083-0, 1983.

Hipsey, M. R., Bruce, L. C., and Hamilton, D. P.: GLM - General Lake Model: Model overview and user information, The University of Western Perth, Perth, Australia, 2014.

Hocking, G. C. and Straškraba, M.: The Effect of Light Extinction on Thermal Stratification in Reservoirs and Lakes, Int. Rev. Hydrobiol., 84, 535-556, https://doi.org/10.1002/iroh.199900046, 1999. 
Holgerson, M. A., Farr, E. R., and Raymond, P. A.: Gas transfer velocities in small forested ponds, J. Geophys. Res.-Biogeo., 122, 1011-1021, https://doi.org/10.1002/2016JG003734, 2017.

Hostetler, S. W. and Bartlein, P. J.: Simulation of lake evaporation with application to modeling lake level variations of HarneyMalheur Lake, Oregon, Water Resour. Res., 26, 2603-2612, https://doi.org/10.1029/WR026i010p02603, 1990.

Hsieh, Y.: Modeling ice cover and water temperature of Lake Mendota, PhD Thesis, University of Wisconsin-Madison, Madison, Wisconsin, USA, 2012.

Idso, S. B.: On the concept of lake stability, Limnol. Oceanogr., 18, 681-683, 1973.

Imberger, J. and Parker, G.: Mixed layer dynamics in a lake exposed to a spatially variable wind field, Limnol. Oceanogr., 30, 473488,1985

Imberger, J. and Patterson, J. C.: Dynamic reservoir simulation model - DYRESM: 5, in: Transport Models for Inland and Coastal Waters, edited by: Fischer, H. B., 310-361, Academic Press, 1981.

Imberger, J., Loh, I., Hebbert, B., and Patterson, J.: Dynamics of Reservoir of Medium Size, J. Hydraul. Div., 104, 725-743, 1978.

Imerito, A.: Dynamic Reservoir Simulation Model DYRESM v4.0 Science Manual, University of Western Australia Centre for Water Research, 2010.

IPCC: Summary for Policymakers, in: Climate Change 2013: The Physical Science Basis. Contribution of Working Group I to the Fifth Assessment Report of the Intergovernmental Panel on Climate Change, edited by: Stocker, T., Qin, D., Plattner, G.-K., Tignor, M., Allen, S. K., Boschung, J., Nauels, A., Xia, Y., Bex, V., and Midgley, P. M., 3-29, Cambridge University Press, Cambridge, United Kingdom and New York, NY, USA, 2013.

Jakkila, J., Leppäranta, M., Kawamura, T., Shirasawa, K., and Salonen, K.: Radiation transfer and heat budget during the ice season in Lake Pääjärvi, Finland, Aquat. Ecol., 43, 681-692, https://doi.org/10.1007/s10452-009-9275-2, 2009.

Jiang, L., Fang, X., Stefan, H. G., Jacobson, P. C., and Pereira, D. L.: Oxythermal habitat parameters and identifying cisco refuge lakes in Minnesota under future climate scenarios using variable benchmark periods, Ecol. Model., 232, 14-27, https://doi.org/10.1016/j.ecolmodel.2012.02.014, 2012.

Jöhnk, K. D., Huisman, J., Sharples, J., Sommeijer, B., Visser, P. M., and Stroom, J. M.: Summer heatwaves promote blooms of harmful cyanobacteria, Glob. Change Biol., 14, 495-512, https://doi.org/10.1111/j.1365-2486.2007.01510.x, 2008.

Kara, E. L., Hanson, P., Hamilton, D., Hipsey, M. R., McMahon, K. D., Read, J. S., Winslow, L., Dedrick, J., Rose, K., Carey, C. C., Bertilsson, S., da Motta Marques, D., Beversdorf, L., Miller, T., Wu, C., Hsieh, Y.-F., Gaiser, E., and Kratz, T.: Time-scale dependence in numerical simulations: Assessment of physical, chemical, and biological predictions in a stratified lake at temporal scales of hours to months, Environ. Model. Softw., 35, 104-121, https://doi.org/10.1016/j.envsoft.2012.02.014, 2012.

Kerimoglu, O. and Rinke, K.: Stratification dynamics in a shallow reservoir under different hydro-meteorological scenarios and operational strategies, Water Resour. Res., 49, 7518-7527, https://doi.org/10.1002/2013WR013520, 2013.

Kimura, N., Wu, C. H., Hoopes, J. A., and Tai, A.: Diurnal Dynamics in a Small Shallow Lake under Spatially Nonuniform
Wind and Weak Stratification, J. Hydraul. Eng., 142, 04016047, https://doi.org/10.1061/(ASCE)HY.1943-7900.0001190, 2016.

Kirillin, G.: Modeling the impact of global warming on water temperature and seasonal mixing regimes in small temperate lakes, Boreal Environ. Res., 15, 279-293, 2010.

Kirillin, G., Leppäranta, M., Terzhevik, A., Granin, N., Bernhardt, J., Engelhardt, C., Efremova, T., Golosov, S., Palshin, N., Sherstyankin, P., Zdorovennova, G., and Zdorovennov, R.: Physics of seasonally ice-covered lakes: a review, Aquat. Sci., 74, 659-682, https://doi.org/10.1007/s00027-012-0279-y, 2012.

Kniffin, M.: Groundwater status report prepared for Friends of lake Wingra, Edgewood College, Madison, Wisconsin, USA, available at: https://www.lakewingra.org/download/lake_and_ watershed_ecology/groundwaterstatusreport.pdf (last access: 11 November 2016), 2011.

Kraemer, B. M., Anneville, O., Chandra, S., Dix, M., Kuusisto, E., Livingstone, D. M., Rimmer, A., Schladow, S. G., Silow, E., Sitoki, L. M., Tamatamah, R., Vadeboncoeur, Y., and McIntyre, P. B.: Morphometry and average temperature affect lake stratification responses to climate change, Geophys. Res. Lett., 42, 4981-4988, https://doi.org/10.1002/2015GL064097, 2015.

Krohelski, J. T., Lin, Y.-F., Rose, W. J., and Hunt, R. J.: Simulation of Fish, Mud, and Crystal Lakes and the shallow groundwater system, Dane County, Wisconsin, USGS Numbered Series, U.S. Geological Survey, available at: http://pubs.er.usgs gov/publication/wri024014 (last access: 24 November 2015), 2002.

Lathrop, R. C., Carpenter, S. R., and Rudstam, L. G.: Water clarity in Lake Mendota since 1900: responses to differing levels of nutrients and herbivory, Can. J. Fish. Aquat. Sci., 53, 2250-2261, https://doi.org/10.1139/f96-187, 1996.

Leppäranta, M., Lindgren, E., and Shirasawa, K.: The heat budget of Lake Kilpisjärvi in the Arctic tundra, Hydrol. Res., 48, 969980, https://doi.org/10.2166/nh.2016.171, 2016.

Livingstone, D. M.: Impact of Secular Climate Change on the Thermal Structure of a Large Temperate Central European Lake, Clim. Change, 57, 205-225, https://doi.org/10.1023/A:1022119503144, 2003.

Luhtala, H. and Tolvanen, H.: Optimizing the Use of Secchi Depth as a Proxy for Euphotic Depth in Coastal Waters: An Empirical Study from the Baltic Sea, ISPRS Int. J. Geo-Inf., 2, 1153-1168, https://doi.org/10.3390/ijgi2041153, 2013.

Lynch, A. J., Taylor, W. W., Beard Jr., T. D., and Lofgren, B. M.: Climate change projections for lake whitefish (Coregonus clupeaformis) recruitment in the 1836 Treaty Waters of the Upper Great Lakes, J. Gt. Lakes Res., 41, 415-422, https://doi.org/10.1016/j.jglr.2015.03.015, 2015.

MacIntyre, S. and Melack, J. M.: Mixing dynamics in lakes across climatic zones, in: Lake Ecosystem Ecology: A Global Perspective, edited by: Likens, G. E., 86-95, Academic Press, San Diego, CA, 2010.

MacKay, M. D., Neale, P. J., Arp, C. D., De Senerpont Domis, L. N., Fang, X., Gal, G., Jöhnk, K. D., Kirillin, G., Lenters, J. D., Litchman, E., MacIntyre, S., Marsh, P., Melack, J., Mooij, W. M., Peeters, F., Quesada, A., Schladow, S. G., Schmid, M., Spence, C., and Stokesr, S. L.: Modeling lakes and reservoirs in the climate system, Limnol. Oceanogr., 54, 2315-2329, https://doi.org/10.4319/lo.2009.54.6_part_2.2315, 2009. 
Magee, M. R. and Wu, C. H.: Effects of changing climate on ice cover in three morphometrically different lakes, Hydrol. Process., 31, 308-323, https://doi.org/10.1002/hyp.10996, 2017.

Magee, M. R., Wu, C. H., Robertson, D. M., Lathrop, R. C., and Hamilton, D. P.: Trends and abrupt changes in 104 years of ice cover and water temperature in a dimictic lake in response to air temperature, wind speed, and water clarity drivers, Hydrol. Earth Syst. Sci., 20, 1681-1702, https://doi.org/10.5194/hess-20-16812016, 2016.

Magnuson, J. J., Benson, B. J., and Kratz, T. K.: Temporal coherence in the limnology of a suite of lakes in Wisconsin, USA, Freshw. Biol., 23, 145-159, https://doi.org/10.1111/j.13652427.1990.tb00259.x, 1990.

Mantyka-Pringle, C. S., Martin, T. G., Moffatt, D. B., Linke, S., and Rhodes, J. R.: Understanding and predicting the combined effects of climate change and land-use change on freshwater macroinvertebrates and fish, J. Appl. Ecol., 51, 572-581, https://doi.org/10.1111/1365-2664.12236, 2014.

McKee, T. B., Doesken, N. J., Davey, C. A., and Pielke, S.: Climate data continuity with ASOS. Report for period April 1996 through June 2000, Colorado Climate Center, Department of Atmospheric Science, Colorado State University, Fort Collins, CO, 2000.

Meehl, G. A. and Tebaldi, C.: More Intense, More Frequent, and Longer Lasting Heat Waves in the 21st Century, Science, 305, 994-997, https://doi.org/10.1126/science.1098704, 2004.

Nõges, P., Nõges, T., Ghiani, M., Paracchini, B., Pinto Grande, J., and Sena, F.: Morphometry and trophic state modify the thermal response of lakes to meteorological forcing, Hydrobiologia, 667, 241-254, https://doi.org/10.1007/s10750-011-0691-7, 2011.

NTL LTER: North Temperate Lakes LTER: Snow and Ice Depth 1982-current, available at: doi:10.6073/pasta/e323699d2b7ed56ef29357dbdbbb3458 (last access: 25 July 2015), 2012a.

NTL LTER: North Temperature Lakes LTER: Physical Limnology of Primary Study Lakes 1981-current, available at: doi:10.6073/pasta/2ce2dedbf9a0759bacbbff235298bc5f, (last access: 25 July 2015), 2012b.

O'Reilly, C. M., Sharma, S., Gray, D. K., Hampton, S. E., Read, J. S., Rowley, R. J., Schneider, P., Lenters, J. D., McIntyre, P. B., Kraemer, B. M., Weyhenmeyer, G. A., Straile, D., Dong, B., Adrian, R., Allan, M. G., Anneville, O., Arvola, L., Austin, J., Bailey, J. L., Baron, J. S., Brookes, J. D., de Eyto, E., Dokulil, M. T., Hamilton, D. P., Havens, K., Hetherington, A. L., Higgins, S. N., Hook, S., Izmest'eva, L. R., Joehnk, K. D., Kangur, K., Kasprzak, P., Kumagai, M., Kuusisto, E., Leshkevich, G., Livingstone, D. M., MacIntyre, S., May, L., Melack, J. M., MuellerNavarra, D. C., Naumenko, M., Noges, P., Noges, T., North, R. P., Plisnier, P.-D., Rigosi, A., Rimmer, A., Rogora, M., Rudstam, L. G., Rusak, J. A., Salmaso, N., Samal, N. R., Schindler, D. E., Schladow, S. G., Schmid, M., Schmidt, S. R., Silow, E., Soylu, M. E., Teubner, K., Verburg, P., Voutilainen, A., Watkinson, A., Williamson, C. E., and Zhang, G.: Rapid and highly variable warming of lake surface waters around the globe, Geophys. Res. Lett., 42, 10773-10781, https://doi.org/10.1002/2015GL066235, 2015.

Paerl, H. W. and Paul, V. J.: Climate change: Links to global expansion of harmful cyanobacteria, Water Res., 46, 1349-1363, https://doi.org/10.1016/j.watres.2011.08.002, 2012.
Palmer, M. E., Yan, N. D., and Somers, K. M.: Climate change drives coherent trends in physics and oxygen content in North American lakes, Clim. Change, 124, 285-299, https://doi.org/10.1007/s10584-014-1085-4, 2014.

Patterson, J. C. and Hamblin, P. F.: Thermal simulation of a lake with winter ice cover, Limnol. Oceanogr., 33, 323-338, https://doi.org/10.4319/lo.1988.33.3.0323, 1988.

Perroud, M., Goyette, S., Martynov, A., Beniston, M., and Anneville, O.: Simulation of multiannual thermal profiles in deep Lake Geneva: a comparison of one-dimensional lake models, Limnol. Oceanogr.-Methods, 54, 1574-1594, 2009.

Pryor, S. C., Barthelmie, R. J., and Kjellström, E.: Potential climate change impact on wind energy resources in northern Europe: analyses using a regional climate model, Clim. Dynam., 25, 815-835, https://doi.org/10.1007/s00382-005-0072-x, 2005.

Read, J. S., Hamilton, D. P., Jones, I. D., Muraoka, K., Winslow, L. A., Kroiss, R., Wu, C. H., and Gaiser, E.: Derivation of lake mixing and stratification indices from high-resolution lake buoy data, Environ. Model. Softw., 26, 1325-1336, https://doi.org/10.1016/j.envsoft.2011.05.006, 2011.

Read, J. S., Hamilton, D. P., Desai, A. R., Rose, K. C., MacIntyre, S., Lenters, J. D., Smyth, R. L., Hanson, P. C., Cole, J. J., Staehr, P. A., Rusak, J. A., Pierson, D. C., Brookes, J. D., Laas, A., and Wu, C. H.: Lake-size dependency of wind shear and convection as controls on gas exchange, Geophys. Res. Lett., 39, L09405, https://doi.org/10.1029/2012GL051886, 2012.

Rempfer, J., Livingstone, D. M., Blodau, C., Forster, R., Niederhauser, P., and Kipfer, R.: The effect of the exceptionally mild European winter of 2006-2007 on temperature and oxygen profiles in lakes in Switzerland: A foretaste of the future?, Limnol. Oceanogr., 55, 2170-2180, https://doi.org/10.4319/lo.2010.55.5.2170, 2010.

Rice, E., Dam, H. G., and Stewart, G.: Impact of Climate Change on Estuarine Zooplankton: Surface Water Warming in Long Island Sound Is Associated with Changes in Copepod Size and Community Structure, Estuaries Coasts, 38, 13-23, https://doi.org/10.1007/s12237-014-9770-0, 2015.

Robertson, D. M.: The use of lake water temperature and ice cover as climatic indicators, $\mathrm{PhD}$ Thesis, University of WisconsinMadison, Madison, Wisconsin, USA, 1989.

Robertson, D. M. and Ragotzkie, R. A.: Changes in the thermal structure of moderate to large sized lakes in response to changes in air temperature, Aquat. Sci., 52, 360-380, https://doi.org/10.1007/BF00879763, 1990.

Rodionov, S. and Overland, J. E.: Application of a sequential regime shift detection method to the Bering Sea ecosystem, ICES J. Mar. Sci. J. Cons., 62, 328-332, https://doi.org/10.1016/j.icesjms.2005.01.013, 2005.

Rodionov, S. N.: A sequential algorithm for testing climate regime shifts, Geophys. Res. Lett., 31, L09204, https://doi.org/10.1029/2004GL019448, 2004.

Rogers, C. K., Lawrence, G. A., and Hamblin, P. F.: Observations and numerical simulation of a shallow icecovered midlatitude lake, Limnol. Oceanogr., 40, 374-385, https://doi.org/10.4319/lo.1995.40.2.0374, 1995.

Rose, K. C., Greb, S. R., Diebel, M., and Turner, M. G.: Annual precipitation regulates spatial and temporal drivers of lake water clarity, Ecol. Appl., 27, 632-643, https://doi.org/10.1002/eap.1471, 2017. 
Rueda, F. and Schladow, G.: Mixing and stratification in lakes of varying horizontal length scales: Scaling arguments and energy partitioning, Limnol. Oceanogr., 54, 2003-2017, https://doi.org/10.4319/lo.2009.54.6.2003, 2009.

Schindler, D. W., Beaty, K. G., Fee, E. J., Cruikshank, D. R., Debruyn, E. R., Findlay, D. L., Linsey, G. A., Shearer, J. A., Stainton, M. P., and Turner, M. A.: Effects of climatic warming on lakes of the central boreal forest, Science, 250, 967-970, https://doi.org/10.1126/science.250.4983.967, 1990.

Schmid, M. and Köster, O.: Excess warming of a Central European lake driven by solar brightening, Water Resour. Res., 52, 81038116, https://doi.org/10.1002/2016WR018651, 2016.

Sharma, S., Vander Zanden, M. J., Magnuson, J. J., and Lyons, J.: Comparing Climate Change and Species Invasions as Drivers of Coldwater Fish Population Extirpations, PLoS ONE, 6, e22906, https://doi.org/10.1371/journal.pone.0022906, 2011.

Shimoda, Y., Azim, M. E., Perhar, G., Ramin, M., Kenney, M. A., Sadraddini, S., Gudimov, A., and Arhonditsis, G. B.: Our current understanding of lake ecosystem response to climate change: What have we really learned from the north temperate deep lakes?, J. Gt. Lakes Res., 37, 173-193, https://doi.org/10.1016/j.jglr.2010.10.004, 2011.

Smith, D. G. and Hoover, M.: Standardization of Secchi disk measurements, including use of a viewer box, in Proceedings of the 2000 National Water Quality Monitoring Conference. available at: http://acwi.gov/monitoring/nwqmc.org/2000proceeding/ papers/pap_smith.pdf (last access: 20 July 2016), 2000.

Snortheim, C. A., Hanson, P. C., McMahon, K. D., Read, J. S., Carey, C. C., and Dugan, H. A.: Meteorological drivers of hypolimnetic anoxia in a eutrophic, north temperate lake, Ecol. Model., 343, 39-53, https://doi.org/10.1016/j.ecolmodel.2016.10.014, 2017.

Stefan, H. G., Hondzo, M., Fang, X., Eaton, J. G., and McCormick, J. H.: Simulated long term temperature and dissolved oxygen characteristics of lakes in the north-central United States and associated fish habitat limits, Limnol. Oceanogr., 41, 1124-1135, https://doi.org/10.4319/1o.1996.41.5.1124, 1996.

Stewart, K. M.: Physical limnology of some Madison lakes, PhD Thesis, University of Wisconsin-Madison, Madison, Wisconsin, USA, 1965.

Tanentzap, A. J., Hamilton, D. P., and Yan, N. D.: Calibrating the Dynamic Reservoir Simulation Model (DYRESM) and filling required data gaps for one-dimensional thermal profile predictions in a boreal lake, Limnol. Oceanogr. Methods, 5, 484-494, https://doi.org/10.4319/lom.2007.5.484, 2007.

Tanentzap, A. J., Yan, N. D., Keller, B., Girard, R., Heneberry, J., Gunn, J. M., Hamilton, D. P., and Taylor, P. A.: Cooling lakes while the world warms: Effects of forest regrowth and increased dissolved organic matter on the thermal regime of a temperate, urban lake, Limnol. Oceanogr., 53, 404-410, https://doi.org/10.4319/lo.2008.53.1.0404, 2008.

Tebaldi, C., Smith, R. L., Nychka, D., and Mearns, L. O.: Quantifying Uncertainty in Projections of Regional Climate Change: A Bayesian Approach to the Analysis of Multimodel Ensembles, J. Climate, 18, 1524-1540, https://doi.org/10.1175/JCLI3363.1, 2005.

Thomas, C. D., Cameron, A., Green, R. E., Bakkenes, M., Beaumont, L. J., Collingham, Y. C., Erasmus, B. F. N., de Siqueira, M. F., Grainger, A., Hannah, L., Hughes, L., Huntley, B., van
Jaarsveld, A. S., Midgley, G. F., Miles, L., Ortega-Huerta, M. A., Townsend Peterson, A., Phillips, O. L., and Williams, S. E.: Extinction risk from climate change, Nature, 427, 145-148, https://doi.org/10.1038/nature02121, 2004.

Thompson, R., Kamenik, C., and Schmidt, R.: Ultra-sensitive Alpine lakes and climate change, J. Limnol., 64, 139-152, 2005.

Van Cleave, K., Lenters, J. D., Wang, J., and Verhamme, E. M.: A regime shift in Lake Superior ice cover, evaporation, and water temperature following the warm El Niñ winter of 1997-1998, Limnol. Oceanogr., 59, 1889-1898, https://doi.org/10.4319/lo.2014.59.6.1889, 2014.

Vautard, R., Cattiaux, J., Yiou, P., Thépaut, J.-N., and Ciais, P.: Northern Hemisphere atmospheric stilling partly attributed to an increase in surface roughness, Nat. Geosci., 3, 756-761, https://doi.org/10.1038/ngeo979, 2010.

Verburg, P. and Hecky, R. E.: The physics of the warming of Lake Tanganyika by climate change, Limnol. Oceanogr., 54, 24182430, 2009.

Voutilainen, A., Huttula, T., Juntunen, J., Rahkola-Sorsa, M., Rasmus, K., and Viljanen, M.: Diverging site-specific trends in the water temperature of a large boreal lake in winter and summer due to mixed effects of local features and climate change, Boreal Environ. Res., 19, 104-114, 2014.

Weinberger, S. and Vetter, M.: Using the hydrodynamic model DYRESM based on results of a regional climate model to estimate water temperature changes at Lake Ammersee, Ecol. Model., 244, 38-48, https://doi.org/10.1016/j.ecolmodel.2012.06.016, 2012.

Wilhelm, S., Hintze, T., Livingstone, D. M., and Adrian, R.: Long-term response of daily epilimnetic temperature extrema to climate forcing, Can. J. Fish. Aquat. Sci., 63, 2467-2477, https://doi.org/10.1139/f06-140, 2006.

Williams, D. T., Drummond, G. R., Ford, D. E., and Robey, D. L.: Determination of light extinction coefficients in lakes and reservoirs, in Proceedings of the Symposium on Surface Water Impoundments, 1329-1335, Minneapolis, MN, USA, 1980.

Winslow, L. A., Read, J. S., Hansen, G. J. A., and Hanson, P. C.: Small lakes show muted climate change signal in deepwater temperatures, Geophys. Res. Lett., 42, 355-361, https://doi.org/10.1002/2014GL062325, 2015.

Woo, M.: Cold Region Atmospheric and Hydrologic Studies. The Mackenzie GEWEX Experience: Volume 2: Hydrologic Processes, Springer Science \& Business Media, 2007.

Woolway, R. I., Jones, I. D., Maberly, S. C., French, J. R., Livingstone, D. M., Monteith, D. T., Simpson, G. L., Thackeray, S. J., Andersen, M. R., Battarbee, R. W., DeGasperi, C. L., Evans, C. D., Eyto, E. de, Feuchtmayr, H., Hamilton, D. P., Kernan, M., Krokowski, J., Rimmer, A., Rose, K. C., Rusak, J. A., Ryves, D. B., Scott, D. R., Shilland, E. M., Smyth, R. L., Staehr, P. A., Thomas, R., Waldron, S., and Weyhenmeyer, G. A.: Diel Surface Temperature Range Scales with Lake Size, PLOS ONE, 11, e0152466, https://doi.org/10.1371/journal.pone.0152466, 2016.

Woolway, R. I., Meinson, P., Nõges, P., Jones, I. D., and Laas, A. Atmospheric stilling leads to prolonged thermal stratification in a large shallow polymictic lake, Clim. Change, 141, 759-773, https://doi.org/10.1007/s10584-017-1909-0, 2017a.

Woolway, R. I., Dokulil, M. T., Marszelewski, W., Schmid, M., Bouffard, D., and Merchant, C. J.: Warming of Central European lakes and their response to the 1980s climate regime shift, 
Clim. Change, 142, 505-520, https://doi.org/10.1007/s10584017-1966-4, 2017b.

Wüest, A. and Lorke, A.: Small-Scale Hydrodynamics in Lakes, Annu. Rev. Fluid Mech., 35, 373-412, https://doi.org/10.1146/annurev.fluid.35.101101.161220, 2003.

Yao, H., Samal, N. R., Joehnk, K. D., Fang, X., Bruce, L. C., Pierson, D. C., Rusak, J. A., and James, A.: Comparing ice and temperature simulations by four dynamic lake models in Harp Lake: past performance and future predictions, Hydrol. Process., 28, 4587-4601, https://doi.org/10.1002/hyp.10180, 2014.

Yeates, P. S. and Imberger, J.: Pseudo two-dimensional simulations of internal and boundary fluxes in stratified lakes and reservoirs, Int. J. River Basin Manag., 1, 297-319, https://doi.org/10.1080/15715124.2003.9635214, 2003.
Ying, L., Shen, Z., and Piao, S.: The recent hiatus in global warming of the land surface: Scale-dependent breakpoint occurrences in space and time, Geophys. Res. Lett., 42, 6471-6478, https://doi.org/10.1002/2015GL064884, 2015.

Zhong, Y., Notaro, M., Vavrus, S. J., and Foster, M. J.: Recent accelerated warming of the Laurentian Great Lakes: Physical drivers, Limnol. Oceanogr., 61, 1762-1786, https://doi.org/10.1002/lno.10331, 2016. 